NASA/TM-2004-212935

\title{
Demonstration of Single Axis Combined Attitude Control and Energy Storage Using Two Flywheels
}

Barbara H. Kenny

Glenn Research Center, Cleveland, Ohio

Ralph Jansen and Peter Kascak

University of Toledo, Toledo, Ohio

Timothy Dever

QSS Group, Inc., Cleveland, Ohio

Walter Santiago

Glenn Research Center, Cleveland, Ohio 
Since its founding, NASA has been dedicated to the advancement of aeronautics and space science. The NASA Scientific and Technical Information (STI) Program Office plays a key part in helping NASA maintain this important role.

The NASA STI Program Office is operated by Langley Research Center, the Lead Center for NASA's scientific and technical information. The NASA STI Program Office provides access to the NASA STI Database, the largest collection of aeronautical and space science STI in the world. The Program Office is also NASA's institutional mechanism for disseminating the results of its research and development activities. These results are published by NASA in the NASA STI Report Series, which includes the following report types:

- TECHNICAL PUBLICATION. Reports of completed research or a major significant phase of research that present the results of NASA programs and include extensive data or theoretical analysis. Includes compilations of significant scientific and technical data and information deemed to be of continuing reference value. NASA's counterpart of peerreviewed formal professional papers but has less stringent limitations on manuscript length and extent of graphic presentations.

- TECHNICAL MEMORANDUM. Scientific and technical findings that are preliminary or of specialized interest, e.g., quick release reports, working papers, and bibliographies that contain minimal annotation. Does not contain extensive analysis.

- CONTRACTOR REPORT. Scientific and technical findings by NASA-sponsored contractors and grantees.
- CONFERENCE PUBLICATION. Collected papers from scientific and technical conferences, symposia, seminars, or other meetings sponsored or cosponsored by NASA.

- SPECIAL PUBLICATION. Scientific, technical, or historical information from NASA programs, projects, and missions, often concerned with subjects having substantial public interest.

- TECHNICAL TRANSLATION. Englishlanguage translations of foreign scientific and technical material pertinent to NASA's mission.

Specialized services that complement the STI Program Office's diverse offerings include creating custom thesauri, building customized databases, organizing and publishing research results ... even providing videos.

For more information about the NASA STI Program Office, see the following:

- Access the NASA STI Program Home Page at http://www.sti.nasa.gov

- E-mail your question via the Internet to help@sti.nasa.gov

- Fax your question to the NASA Access Help Desk at 301-621-0134

- Telephone the NASA Access Help Desk at 301-621-0390

- Write to:

NASA Access Help Desk

NASA Center for AeroSpace Information 7121 Standard Drive

Hanover, MD 21076 
NASA/TM-2004-212935

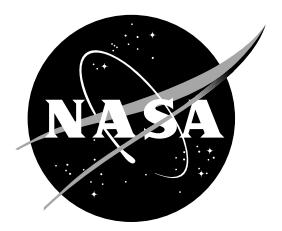

\section{Demonstration of Single Axis Combined Attitude Control and Energy Storage Using Two Flywheels}

Barbara H. Kenny

Glenn Research Center, Cleveland, Ohio

Ralph Jansen and Peter Kascak

University of Toledo, Toledo, Ohio

Timothy Dever

QSS Group, Inc., Cleveland, Ohio

Walter Santiago

Glenn Research Center, Cleveland, Ohio

Prepared for the

2004 Aerospace Conference

sponsored by the Institute of Electrical and Electronics Engineers

Big Sky, Montana, March 6-13, 2004

National Aeronautics and

Space Administration

Glenn Research Center 


\section{Acknowledgments}

The authors would like to gratefully acknowledge the outstanding support of Ramon Lebron-Velilla, Larry Trase, Don Fong, and Vicki Crable in the development and operation of the flywheel facility.

This report is a preprint of a paper intended for presentation at a conference. Because of changes that may be made before formal publication, this preprint is made available with the understanding that it will not be cited or reproduced without the permission of the author.

Trade names or manufacturers' names are used in this report for identification only. This usage does not constitute an official endorsement, either expressed or implied, by the National Aeronautics and Space Administration.

Available from

NASA Center for Aerospace Information 7121 Standard Drive

Hanover, MD 21076
National Technical Information Service 5285 Port Royal Road Springfield, VA 22100 


\section{Demonstration of Single Axis Combined Attitude Control and Energy Storage Using Two Flywheels}

\author{
Barbara H. Kenny \\ National Aeronautics and \\ Space Administration \\ Glenn Research Center \\ Cleveland, Ohio 44135 \\ Barbara.H.Kenny@grc.nasa.gov
}

\author{
Ralph Jansen and Peter Kascak \\ University of Toledo \\ Toledo, Ohio 43606 \\ Ralph.Jansen@grc.nasa.gov \\ Peter.Kascak@grc.nasa.gov
}

\author{
Timothy Dever \\ QSS Group, Inc. \\ Cleveland, Ohio 44135 \\ Timothy.Dever@grc.nasa.gov
}

\author{
Walter Santiago \\ National Aeronautics and \\ Space Administration \\ Glenn Research Center \\ Cleveland, Ohio 44135 \\ Walter.Santiago@grc.nasa.gov
}

Abstract-The energy storage and attitude control subsystems of the typical satellite are presently distinct and separate. Energy storage is conventionally provided by batteries, either $\mathrm{NiCd}$ or $\mathrm{NiH}$, and active attitude control is accomplished with control moment gyros (CMGs) or reaction wheels. An overall system mass savings can be realized if these two subsystems are combined using multiple flywheels for simultaneous kinetic energy storage and momentum transfer. Several authors have studied the control of the flywheels to accomplish this and have published simulation results showing the feasibility and performance. This paper presents the first experimental results showing combined energy storage and momentum control about a single axis using two flywheels.

\section{INTRODUCTION}

The NASA Glenn Research Center has been developing the technology necessary for the use of flywheels on future spacecraft for the last several years. Flywheels, as energy storage devices, offer several advantages over conventional batteries. These include a longer life, greater depth of discharge, less complex thermal management and easier state of charge measurement (rotor speed). In addition, flywheels can also be used as momentum wheels for attitude control. This presents the opportunity to combine two satellite subsystems, energy storage and attitude control, into one, resulting in a lower overall system mass. Several authors have studied this possibility and theoretically proved the feasibility of the idea $[1,2,3,4]$. These papers are generally written from the perspective of the attitude control engineers. In this paper, the control is developed from the power system and motor control perspective.

To combine energy storage and attitude control, there must at a minimum be one flywheel for each degree of freedom required. For example, for one axis of attitude control plus energy storage there must be at least two flywheels; for three axes of attitude control plus energy storage there must be at least four flywheels. More flywheels may be desired in the final configuration for redundancy purposes. The control laws in any case would be similar - the flywheels must be controlled to simultaneously provide the required torque on the spacecraft for attitude control and provide the correct power to the system as an energy storage device. In addition, these functions should be independent, so that a change in the power required by the system does not result in a disturbance torque to the spacecraft and a change in the attitude of the spacecraft does not result in a change in the electrical power available to the loads.

The NASA Glenn Research center has taken the first steps toward demonstrating this technology. Successful energy storage capability was first experimentally demonstrated with a single flywheel in charge, discharge and charge reduction modes [5,6,7]. Next, a control algorithm was developed and simulated to combine single axis attitude control and energy storage [8]. Finally, an experimental facility with two flywheels was constructed so that simultaneous single axis attitude control and energy storage could be demonstrated. Using this facility, this paper will present the first experimental verification of the combined attitude control and energy storage concept.

\begin{tabular}{|c|c|}
\hline \multicolumn{2}{|c|}{ Nomenclature } \\
\hline$\tau_{\text {table }}$ & Torque applied to air table (N-m) \\
\hline$\tau_{\mathrm{em}}$ & $\begin{array}{l}\text { Electro-mechanical torque produced by motor } \\
(\mathrm{N}-\mathrm{m})\end{array}$ \\
\hline $\mathbb{P}_{\mathrm{AC}}$ & AC electrical power supplied to motor (watts) \\
\hline $\mathrm{v}_{\mathrm{qs}}^{\mathrm{r}}$ & $\begin{array}{l}\text { Motor q-axis voltage, expressed in the rotor } \\
\text { reference frame (volts) }\end{array}$ \\
\hline $\mathrm{v}_{\mathrm{ds}}^{\mathrm{r}}$ & $\begin{array}{l}\text { Motor d-axis voltage, expressed in the rotor } \\
\text { reference frame (volts) }\end{array}$ \\
\hline $\mathrm{i}_{\mathrm{qs}}^{\mathrm{r}}$ & $\begin{array}{l}\text { Motor q-axis current, expressed in the rotor } \\
\text { reference frame (amps) }\end{array}$ \\
\hline $\mathrm{i}_{\mathrm{ds}}^{\mathrm{r}}$ & $\begin{array}{l}\text { Motor d-axis current, expressed in the rotor } \\
\text { reference frame (amps) }\end{array}$ \\
\hline $\mathrm{L}_{\mathrm{qs}}$ & Motor q-axis inductance (henries) \\
\hline $\mathrm{L}$ & Motor d-axis inductance (henries) \\
\hline
\end{tabular}

\section{Nomenclature}

$\tau_{\text {table }} \quad$ Torque applied to air table $(\mathrm{N}-\mathrm{m})$

Electro-mechanical torque produced by motor $(\mathrm{N}-\mathrm{m})$

Motor q-axis voltage, expressed in the rotor Motor d-axis voltage, expressed in the rotor reference frame (volts) reference frame (amps)

Motor d-axis current, expressed in the rotor

Motor d-axis inductance (henries) 


\begin{tabular}{|c|c|}
\hline $\mathrm{R}_{\mathrm{s}}$ & Motor resistance (ohms) \\
\hline$\omega_{\mathrm{r}}$ & Motor rotor speed (electrical radians/sec.) \\
\hline$\lambda_{\mathrm{af}}$ & Motor back-EMF constant (volt-sec.) \\
\hline $\mathbb{P}_{\text {DCtotal }}$ & $\begin{array}{l}\text { Total DC power supplied to both flywheels } \\
\text { (watts) }\end{array}$ \\
\hline $\mathrm{P}$ & Number of poles of motor \\
\hline $\mathrm{N}_{\text {axes }}$ & Desired number of axes of attitude control \\
\hline $\mathrm{N}_{\text {flywheels }}$ & $\begin{array}{l}\text { Number of flywheels in a combined attitude } \\
\text { control/energy storage system }\end{array}$ \\
\hline Variable $^{*}$ & Commanded value of variable \\
\hline $\mathrm{I}_{\mathrm{S} / \mathrm{a}}$ & Current from solar array or power supply (amps) \\
\hline $\mathrm{I}_{\text {load }}$ & Current into DC load (amps) \\
\hline$I_{\text {charge }}^{*}$ & Commanded flywheel charging current (amps) \\
\hline$I_{\text {flywheel }}$ & Total DC current into flywheel units (amps) \\
\hline $\mathrm{I}_{\mathrm{D} 1}$ & DC Current into D1 flywheel unit (amps) \\
\hline IHSS & DC Current into HSS flywheel unit (amps) \\
\hline
\end{tabular}

\section{Control Algorithm Development}

The inner-most loop of the overall control algorithm is based on a motor control technique known as field orientation control. This technique allows accurate, high bandwidth torque control of the flywheel motor/generator by regulating rotor reference frame currents that are DC in the steady state. A general description of field orientation of permanent magnet machines can be found in [9] and a specific discussion of the motor control techniques used in the flywheel program can be found in $[10,11]$. The description of the overall flywheel system control given in this paper assumes a basic familiarity with the field orientation technique.

\section{Overall Control Derivation}

The single axis system to be controlled is shown schematically in Figure 1. It consists of two flywheels mounted on an air-bearing table. Table movement is restrained by a load cell that is connected between the outer edge of the table and a fixed point. The load cell measures the net force applied to the table due to the two flywheels. The axial torque on the table can then be computed from $(\mathbf{r} \times \mathbf{F})$. The net steady state torque applied to the table is the sum of the flywheel motor reaction torques as shown in equation 1 .

$$
\tau_{\text {table }}=-\tau_{\mathrm{em} 1}-\tau_{\mathrm{em} 2}
$$

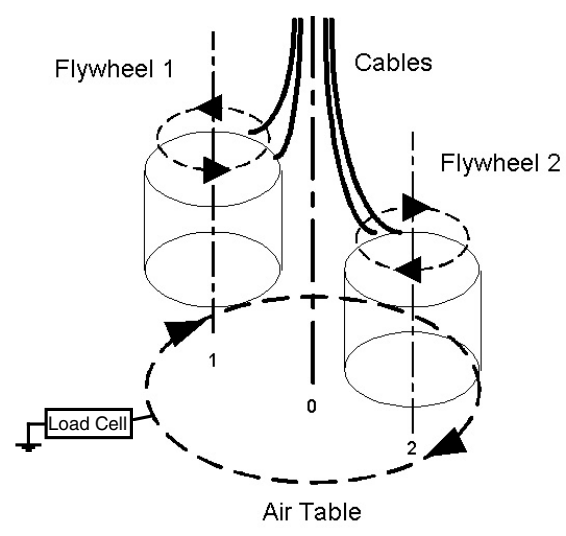

Figure 1.-Test Facility Schematic

Electrically, the motor/generator of each flywheel is connected to the same dc bus through its own inverter and filter as shown in Figure 2. In charge mode, the DC current, $\mathrm{I}_{\text {flywheel, }}$ is positive and the speed of the flywheels is increasing. In discharge mode, the flywheels are decreasing in speed and providing power to the DC bus.

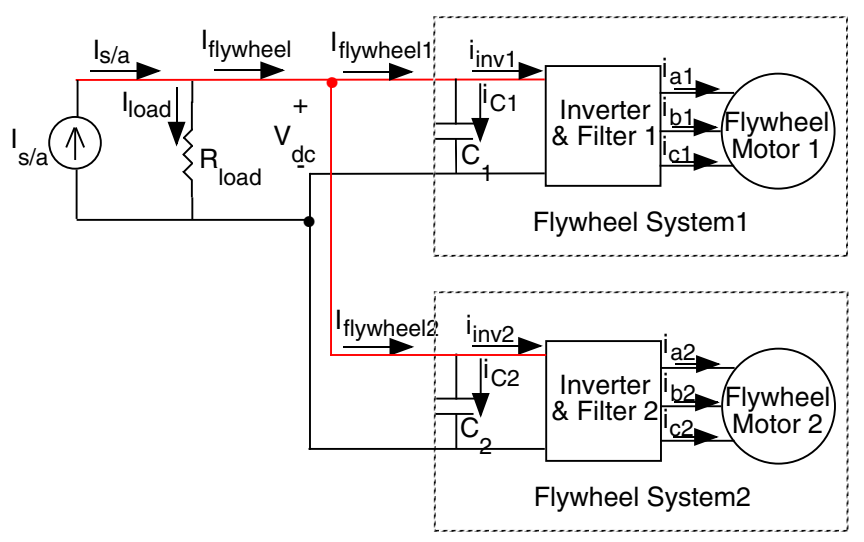

Figure 2.-Electrical Schematic

The AC electrical power supplied to the motor can be expressed using the motor currents and voltages expressed in the rotor reference frame.

$$
\mathbb{P}_{\mathrm{AC}}=\frac{3}{2}\left(\mathrm{v}_{\mathrm{qs}}^{\mathrm{r}} \dot{i}_{\mathrm{qs}}^{\mathrm{r}}+\mathrm{v}_{\mathrm{ds}}^{\mathrm{r}} \dot{1}_{\mathrm{ds}}^{\mathrm{r}}\right)
$$

The motor currents are controlled such that $\mathrm{i}_{\mathrm{ds}}^{\mathrm{r}}$ is regulated to zero and thus (2) reduces to (3).

$$
\mathbb{P}_{\mathrm{AC}}=\frac{3}{2}\left(\mathrm{v}_{\mathrm{qs}}^{\mathrm{r}} \mathrm{i}_{\mathrm{qs}}^{\mathrm{r}}\right)
$$

Equation (4) gives the motor voltage, $\mathrm{v}_{\mathrm{qs}}^{\mathrm{r}}$, from [9]. 


$$
\mathrm{v}_{\mathrm{qs}}^{\mathrm{r}}=\mathrm{i}_{\mathrm{qs}}^{\mathrm{r}} \mathrm{R}_{\mathrm{s}}+\mathrm{L}_{\mathrm{qs}} \frac{\mathrm{d}\left(\mathrm{i}_{\mathrm{qs}}^{\mathrm{r}}\right)}{\mathrm{dt}}+\mathrm{i}_{\mathrm{ds}}^{\mathrm{r}} \omega_{\mathrm{r}} \mathrm{L}_{\mathrm{ds}}+\omega_{\mathrm{r}} \lambda_{\mathrm{af}}
$$

Assuming steady state conditions (under field orientation control, the quantity $\mathrm{i}_{\mathrm{qs}}^{\mathrm{r}}$ is DC in steady state) and neglecting the resistive drop (which is generally small compared to the back EMF term, $\left.\omega_{\mathrm{r}} \lambda_{\mathrm{af}}\right),(4)$ reduces to (5).

$$
\mathrm{v}_{\mathrm{qs}}^{\mathrm{r}} \approx \omega_{\mathrm{r}} \lambda_{\mathrm{af}}
$$

Substituting (5) into (3) results in the expression for the steady state AC electrical power of the motor/generator.

$$
\mathbb{P}_{\mathrm{AC}} \approx \frac{3}{2} \mathrm{i}_{\mathrm{qs}}^{\mathrm{r}} \omega_{\mathrm{r}} \lambda_{\mathrm{af}}
$$

Note that if $\mathrm{i}_{\mathrm{qs}}^{\mathrm{r}}$ is positive and the machine is spinning in the positive direction as defined by Flywheel 1 in Figure 1, then the power is positive. This means that the machine is motoring (charging). Similarly, if $\mathrm{i}_{\mathrm{qs}}^{\mathrm{r}}$ is negative, the power is negative, implying that the machine is generating (discharging). Thus charge and discharge of the flywheel can be regulated by properly controlling $\mathrm{i}_{\mathrm{qs}}^{\mathrm{r}}$.

If the inverter/filter losses are neglected, the DC power supplied to each flywheel is approximately equal to the $\mathrm{AC}$ power shown in (6) in steady state. The total flywheel power for the system is the sum of the power for each individual flywheel.

$$
\begin{gathered}
\mathbb{P}_{\mathrm{DCtotal}} \approx \mathbb{P}_{\mathrm{AC} 1}+\mathbb{P}_{\mathrm{AC} 2}= \\
\frac{3}{2} \mathrm{i}_{\mathrm{q} 1}^{\mathrm{r}} \omega_{\mathrm{r} 1} \lambda_{\mathrm{af} 1}+\frac{3}{2} \mathrm{i}_{\mathrm{qs} 2}^{\mathrm{r}} \omega_{\mathrm{r} 2} \lambda_{\mathrm{af} 2}
\end{gathered}
$$

Equations (1) and (7) form the fundamental basis for the control of the two flywheels to achieve simultaneous attitude control and energy storage. In (1), the control variable is the motor/generator torque, $\tau_{\mathrm{em}}$, while in (7) the control variable is the motor/generator current, $\mathrm{i}_{\mathrm{qs}}^{\mathrm{r}}$. To combine the two equations, the relationship between the motor/generator torque and current must be used and that is given in (8).

$$
\tau_{\mathrm{em}}=\frac{3}{2} \frac{\mathrm{P}}{2} \mathrm{i}_{\mathrm{qs}}^{\mathrm{r}}\left[\lambda_{\mathrm{af}}+\left(\mathrm{L}_{\mathrm{ds}}-\mathrm{L}_{\mathrm{qs}}\right) \mathrm{i}_{\mathrm{ds}}^{\mathrm{r}}\right]
$$

With $\mathrm{i}_{\mathrm{ds}}^{\mathrm{r}}$ regulated to zero, it becomes

$$
\tau_{\mathrm{em}}=\frac{3}{2} \frac{\mathrm{P}}{2} \mathrm{i}_{\mathrm{qs}}^{\mathrm{r}} \lambda_{\mathrm{af}}
$$

Combining (1), (7) and (9), the system control can either be expressed in terms of motor/generator torque, as in (10), or motor/generator current, as in (11).

$$
\begin{gathered}
{\left[\begin{array}{c}
\tau_{\text {table }} \\
\mathbb{P}_{\mathrm{dc}}
\end{array}\right]=\left[\begin{array}{cc}
-1 & -1 \\
\frac{2}{\mathrm{P}_{1}} \omega_{1} & \frac{2}{\mathrm{P}_{2}} \omega_{2}
\end{array}\right]\left[\begin{array}{c}
\tau_{\mathrm{em} 1} \\
\tau_{\mathrm{em} 2}
\end{array}\right]} \\
{\left[\begin{array}{c}
\tau_{\text {table }} \\
\mathbb{P}_{\mathrm{dc}}
\end{array}\right]=\left[\begin{array}{cc}
-\frac{3 \mathrm{P}_{1} \lambda_{\mathrm{af} 1}}{4} & -\frac{3 \mathrm{P}_{2} \lambda_{\mathrm{af} 2}}{4} \\
\frac{3}{2} \omega_{1} \lambda_{\mathrm{af} 1} & \frac{3}{2} \omega_{2} \lambda_{\mathrm{af} 2}
\end{array}\right]\left[\begin{array}{c}
\mathrm{i}_{\mathrm{qs} 1}^{\mathrm{r}} \\
\mathrm{i}_{\mathrm{qs} 2}^{\mathrm{r}}
\end{array}\right]}
\end{gathered}
$$

Note that (10) can be modified to include additional flywheels and axes of control by determining the relationship between the torque produced by each flywheel motor and its effect on each axis. This will depend on the geometry of a particular configuration but in general, the left hand side vector of (10) will be of length $\left(\mathrm{N}_{\text {axes }}+1\right)$ and the right hand side vector will be of length ( $\left.\mathrm{N}_{\text {flywheels }}\right)$. Equation (11) can then be determined from (10) and (9) for an arbitrary number of flywheels.

\section{Determining Commanded Control Quantities}

In our system, fast motor torque control is achieved through the use of the field orientation technique and a high bandwidth synchronous frame current regulator [12]. Thus it is most useful to solve (11) for the necessary motor currents given a commanded value of table torque and DC power. This is shown in (12).

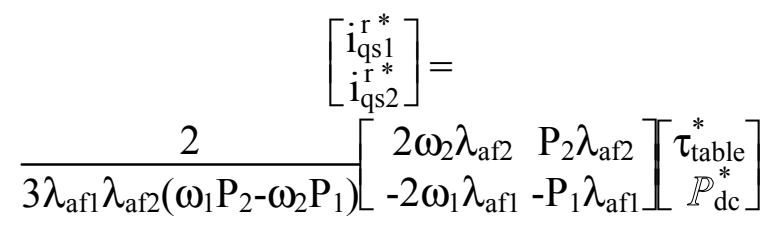

Equation (12) is the same result first given in reference [8]; however, here it is expressed more generally in matrix form.

The commanded values of $\tau_{\text {table }}^{*}$ and $\mathbb{P}_{\mathrm{dc}}^{*}$ can be the result of other control loops or can be commanded directly. For example, the table torque command could be the result of a position feedback loop to control the position of the table. Simulation results for this case are given in [8]. In the results presented herein, $\tau_{\text {table }}^{*}$ is commanded directly. There is no closed loop control on the torque applied to the table.

The power command, $\mathbb{P}_{\mathrm{dc}}^{*}$, is the result of the DC bus regulation algorithm that is described in detail in $[5,6,7]$. It will also be summarized here.

\section{Power Regulation}

There are three modes of operation for the batteries in a spacecraft power system: charge, charge reduction and discharge. The control for the flywheel system in this experimental demonstration is constructed in the same fashion so as to facilitate the eventual demonstration of flywheel energy storage on a spacecraft. 
In charge mode, the solar array produces enough current to charge the flywheels at a setpoint and to provide the required load current. The solar array electronics regulate the DC bus voltage during charge mode. In charge reduction mode, the solar array continues to provide load current but it cannot provide enough current to charge the flywheels at the setpoint. When this occurs, the DC bus voltage regulation function is transferred to the flywheel system. Finally, in discharge mode, the flywheel system provides all of the load current and regulates the DC bus voltage. The features of each mode are given in Table 1 using the variables defined in Fig. 2 where $\mathrm{I}_{\text {charge }}^{*}$ is the commanded charging current.

Table 1.-Flywheel System Operating Mode Characteristics

\begin{tabular}{|c|c|c|}
\hline$\underline{\text { Mode }}$ & $\underline{\text { Current }}$ & $\underline{\underline{\text { DC Bus }}}$ \\
\hline $\begin{array}{c}\text { Foltage } \\
\text { "Charge" }\end{array}$ & $\begin{array}{c}\mathrm{I}_{\mathrm{S} / \mathrm{a}}=\mathrm{I}_{\text {load }}+\mathrm{I}_{\text {charge }}^{*} \\
\mathrm{I}_{\text {flywheel }}=\mathrm{I}_{\text {charge }}^{*}\end{array}$ & $\begin{array}{c}\text { Regulated by } \\
\text { solar array } \\
\text { system }\end{array}$ \\
\hline $\begin{array}{c}\text { Partial Sun } \\
\text { "Charge } \\
\text { Reduction" }\end{array}$ & $\begin{array}{c}\mathrm{I}_{\text {load }}+\mathrm{I}_{\text {charge }}^{*}>\mathrm{I}_{\mathrm{S} / \mathrm{a}}>\mathrm{I}_{\text {load }} \\
\mathrm{I}_{\text {charge }}^{*}>\mathrm{I}_{\text {flywheel }}>0\end{array}$ & $\begin{array}{c}\text { Regulated by } \\
\text { flywheel system }\end{array}$ \\
\hline $\begin{array}{c}\text { Eclipse } \\
\text { "Discharge" }\end{array}$ & $\begin{array}{c}\mathrm{I}_{\text {load }}=-\mathrm{I}_{\text {flywheel }} \\
\mathrm{I}_{\text {flywheel }}<0\end{array}$ & $\begin{array}{c}\text { Regulated by } \\
\text { flywheel system }\end{array}$ \\
\hline
\end{tabular}

In charge mode, the power command, $\mathbb{P}_{\mathrm{dc}}^{*}$, is determined from the combination of a feed-forward term and a feedback term as shown in Figure 3. The feed-forward term is simply the commanded charging current. In an ideal world, where all parameters are known perfectly, this would be sufficient. The feedback term is derived from the comparison of the measured current and the commanded current. It provides error compensation that forces $\mathrm{I}_{\mathrm{flywhee}}$ to track the commanded value. Using the feed-forward term allows the gains on the PI portion to be set much lower than otherwise necessary and results in fast response with less noise on $\mathbb{P}_{\mathrm{dc}}^{*}$.

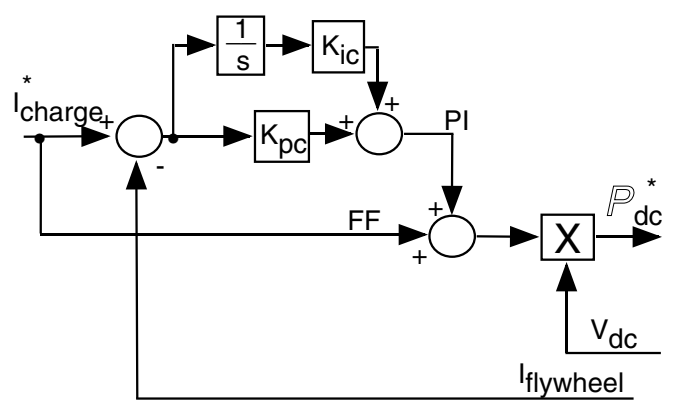

Figure 3.- Charge Mode Controller

In charge reduction and discharge modes, the flywheel system must regulate the DC bus voltage. The block diagram for this algorithm is shown in Fig. 4. Again, there are two components to the controller: the PI portion and a disturbance decoupling (DD) portion. In the decoupling portion, the DC current is measured and used as an early indicator to the controller whether there has been an increase or decrease in load. If there is a sudden increase in load, the capacitor will initially maintain the bus voltage and there will be an increase in the DC current, $\mathrm{I}_{\text {flywheel}}$, to supply the new load. This increase in $\mathrm{I}_{\text {flywheel }}$ is used by the controller increase the DC power command, $\mathbb{P}_{\mathrm{dc}}^{*}$, even before a drop in the DC bus voltage causes the PI portion to respond.

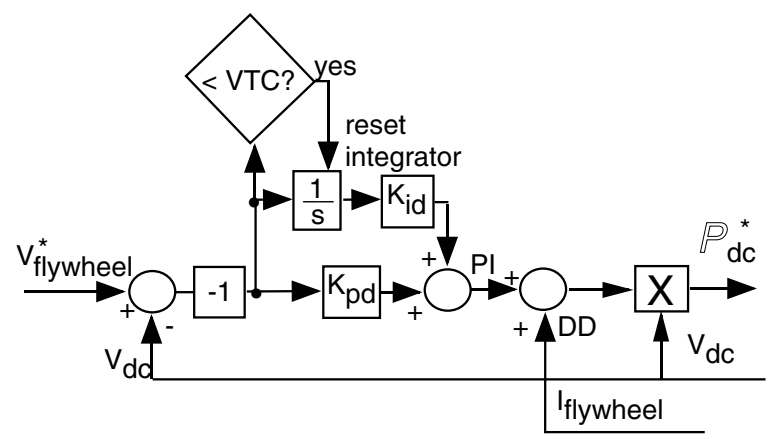

Figure 4.-Discharge and Charge Reduction Controller

In the PI portion the measured DC bus voltage is compared to the commanded DC bus voltage and the error signal is inverted. This is because (using the direction references of Fig. 2) if the DC bus voltage is decreasing, there needs to be an increase in the average inverter current to charge the capacitor and increase the bus voltage, and if the DC bus voltage is increasing, there needs to be a decrease in the inverter current. The PI portion makes up for any inaccuracies in the disturbance decoupling portion and maintains the DC bus voltage at the set point.

The transition from current regulation (Fig. 3) to voltage regulation (Fig. 4) is accomplished in the following manner and shown in Fig. 5. The solar array regulates the bus voltage to a set point value higher than the flywheel regulation set point as long as the solar array current is sufficient to provide both the load and the charging current, $I_{\text {charge }}^{*}$ Once the solar array current begins to drop off, the DC bus voltage begins to fall and the flywheel current,

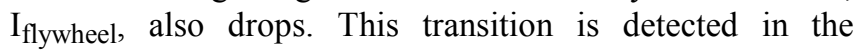
controller by comparing the difference between the actual DC bus voltage and the flywheel set point voltage to the "voltage transition constant", VTC, as seen in Fig. 5. Once this difference is less than the VTC, the integrator in the PI portion of the controller is reset. This reduces the $\mathrm{i}_{\text {inv }}^{*}$ command at point 2 to a value slightly larger than $\mathrm{I}_{\text {flywheel }}$. This value is then compared to the charge current set point, $I_{\text {charge }}^{*}$ If it is less than $I_{\text {charge }}^{*}$, which it will be if the solar array is not producing enough current, then the system transitions into charge reduction mode where the DC bus voltage is regulated by the flywheel system.

Similarly, as the system moves from eclipse into sunlight, the solar array will produce more and more current. When the solar array produces enough current to meet the load demand, the $i_{\text {inv }}^{*}$ command at point 2 in the controller will become positive. When it exceeds the charge current set point, $I_{\text {charge }}^{*}$, the integrator in the current regulator portion 
of the controller is reset and the system transitions back into charge mode where the flywheel system regulates the current into the flywheel and the solar array system regulates the DC bus voltage.

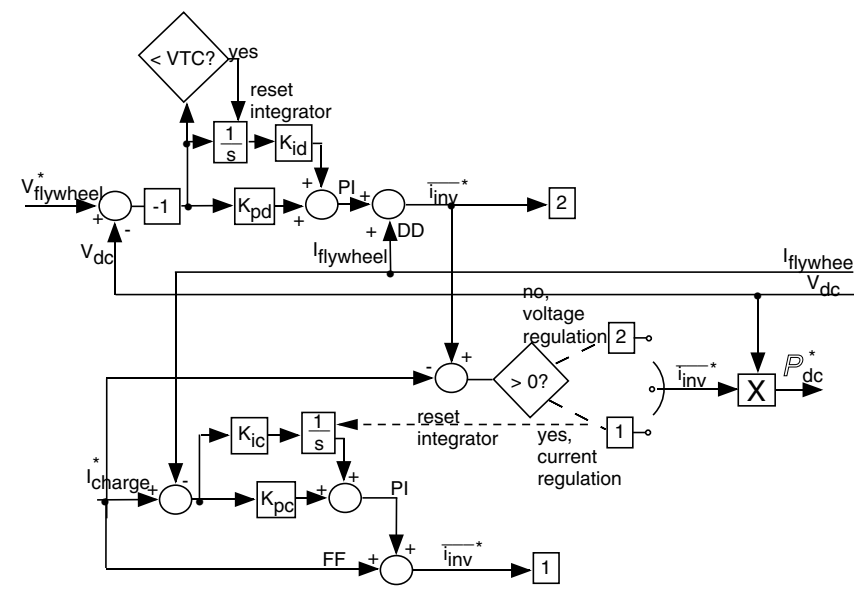

Figure 5.-Combined charge/discharge power regulation control block diagram.

It is important to note that the three modes of operation, charge, charge reduction and discharge, were originally defined based on a battery energy storage system. The flywheel energy storage system is capable of regulating the DC bus voltage at all times, both when charging and discharging, obviating the need for current and voltage regulation modes and the transition between them. This would result in an overall simpler control strategy, even when considering the necessary provisions to prevent overspeed or over-current operation. This modification of the control will be investigated in future efforts.

\section{Overall Control Block Diagram}

The overall system control block diagram is given in Figure 6. Each portion of the controller has been clearly defined and labeled, with references to the corresponding equations if appropriate. Although complex, the control can be broken down into manageable blocks as shown such that improvements in a particular area can be individually developed. For example, a different power and attitude control algorithm block could be evaluated while the rest of the control remained the same.

\section{SIMULATION AND EXPERIMENTAL ASSUMPTIONS AND CONDITIONS}

The next four sections will present a combination of simulation and experimental results. First, the simulation and experimental conditions and equipment will be described in this section. In the next section, the baseline set of simulation and experimental results will be given for the control as described thus far, in particular, Fig. 6 and equation (12). It will be seen that there are some transient disturbances that occur on the power bus due to a step change in the table torque command. Next, in Section 5, simulation and experimental results will be presented for the case where the control algorithm is modified to include the motor and AC side resistances. This modification improves the disturbance rejection of the power system bus during table torque command transients. Finally, in Section 6, a set of experimental results will be presented to show the effect of spinning the two flywheels "backwards" relative to the first two sets of data.

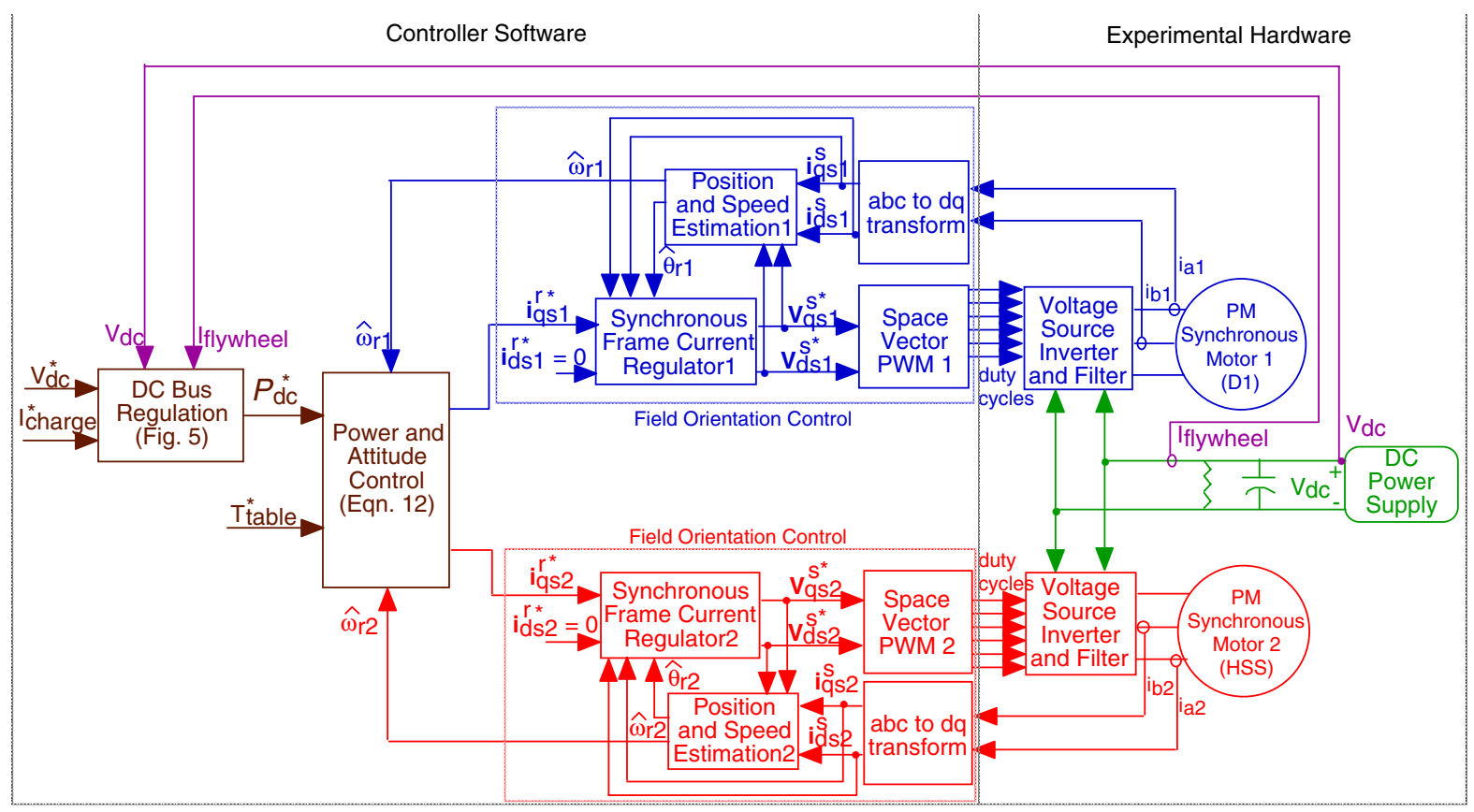

Figure 6.-Overall Flywheel Control System Block Diagram 
The simulations were done using Matlab/Simulink and were based on the block diagram of Figure 6. The PM motors were simulated based on standard motor equations [8]. The switching of the voltage source inverter was not modeled (PWM harmonics were not considered) and the stator resistance of the motor model was increased to account for the switch, conductor and filter resistances for the simulation results in Section 5.

The important control parameters for the two flywheels, known as High Speed Shaft (HSS) and Development 1 (D1), are given in Table 2. It can be seen that the two flywheels are very dissimilar in terms of voltage rating, inertia, back EMF constant and number of motor poles. The use of these two flywheel units was dictated by budget and availability constraints. In any actual flight system, the two flywheels would be designed identically and any differences would be due only to manufacturing tolerances. Although less than ideal, the fact that we can control the system with two different motors and two very different inertias is a testament to the robustness of the control technique.

Table 2.-Parameters of Flywheel Motors

\begin{tabular}{|c|l|l|}
\hline \multicolumn{3}{|l|}{ D1 Motor/Generator Parameters } \\
\hline $\mathrm{J}$ & Rotor polar moment of inertia & $0.0664 \mathrm{~kg}-\mathrm{m}^{2}$ \\
\hline $\mathrm{L}_{\mathrm{q}}$ & Motor q-axis inductance & $25 \mu \mathrm{H}$ \\
\hline $\mathrm{L}_{\mathrm{d}}$ & Motor d-axis inductance & $19 \mu \mathrm{H}$ \\
\hline $\mathrm{R}_{\mathrm{s}}$ & Stator resistance & $0.02 \Omega$ \\
\hline$\lambda_{\mathrm{af}}$ & Back EMF constant & 0.0103 volt-sec. \\
\hline $\mathrm{P}$ & No. of poles & 2 \\
\hline $\mathrm{V}_{\text {nom }}$ & Rated L-N RMS voltage & 45.7 volts \\
\hline $\begin{array}{l}\text { High } \\
\text { Parameters }\end{array}$ & Speed Shaft & Motor/Generator \\
\hline $\mathrm{J}$ & Rotor polar moment of inertia & $0.00377 \mathrm{~kg}-\mathrm{m}^{2}$ \\
\hline $\mathrm{L}_{\mathrm{q}}$ & Motor q-axis inductance & $142 \mu \mathrm{H}$ \\
\hline $\mathrm{L}_{\mathrm{d}}$ & Motor d-axis inductance & $101 \mu \mathrm{H}$ \\
\hline $\mathrm{R}_{\mathrm{s}}$ & Stator resistance & $0.035 \Omega$ \\
\hline$\lambda_{\mathrm{af}}$ & Back EMF constant & 0.0144 volt-sec. \\
\hline $\mathrm{P}$ & No. of poles & 4 \\
\hline $\mathrm{V}_{\text {nom }}$ & Rated L-N RMS voltage & 128 volts \\
\hline
\end{tabular}

The experimental tests were limited to speeds of $12,000 \mathrm{rpm}$ or less because the magnetic bearings for the system had not yet been optimally tuned for higher speed operation. The initial simulation speeds were set to $11,000 \mathrm{rpm}$ to be in the range of the experimental conditions.

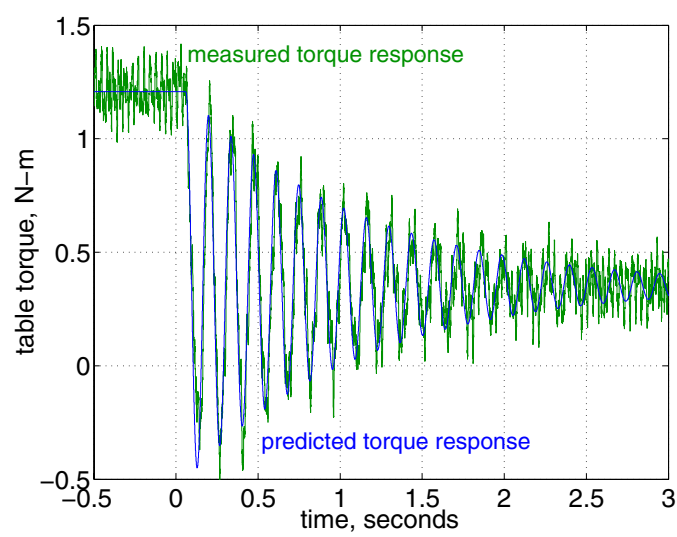

Figure 7.-Air Table Natural Response

The air table dynamics, with the load cell attached, were measured and then modeled to fit the measured data. The air table was moved from an equilibrium position and allowed to return to equilibrium without the influence of the flywheel motors as seen in Fig. 7. This response was modeled as a second order system with a damping factor of .0186 and a natural frequency of $8.57 \mathrm{~Hz}$. Using these factors, the simulated response is also shown on Fig. 7.

Each set of data is grouped according to the three general test conditions listed in Table 3 . These tests demonstrate a representative range of functionality for the combined flywheel system energy storage and single axis attitude control. For each test, a set of data is presented that includes the DC currents (defined in Fig. 2), the DC bus voltage, the torque on the air table, the motor speeds and the motor phase currents.

Table 3.-General Test Conditions for Simulation and Experimental Results

\begin{tabular}{|c|c|c|c|}
\hline$\frac{\text { Test }}{\text { Number }}$ & $\frac{\underline{\text { Power }}}{\text { Regulation }} \frac{\text { Mode }}{\underline{\text { Mode }}}$ & $\frac{\text { Table Torque }}{\text { Command }(\mathrm{N}-\mathrm{m})}$ & Load \\
\hline 1 & $\begin{array}{l}\text { Charge to } \\
\text { Discharge }\end{array}$ & $\mathrm{T}^{*}=0$ & $\begin{array}{l}\text { Step } \\
\text { change }\end{array}$ \\
\hline 2 & Charge & $\mathrm{T}^{*}=0 \rightarrow+0.5 \rightarrow 0$ & $\begin{array}{l}\text { Constant } \\
\text { load }\end{array}$ \\
\hline 3 & Discharge & $\mathrm{T}^{*}=0 \rightarrow-0.5 \rightarrow 0$ & $\begin{array}{l}\text { Constant } \\
\text { load }\end{array}$ \\
\hline
\end{tabular}

\section{SimULATION AND EXPERIMENTAL RESULTS: PART A}

Test 1

In this section, the functionality of the control in the charge and discharge modes with a zero torque command on the table is shown with simulation and experimental results. Figures 8 through 13 give the simulation results and Figures 14 through 19 give the experimental results for the Test 1 conditions. Point "a" is a transition from one commanded current value to another while in charge mode, point " $b$ " is 
a transition from charge to discharge mode, point "c" is a step change in the electrical load and point " $d$ " is a transition from discharge to charge mode. (Note: point " $d$ " is not shown in the experimental results because the time capture setting was too small. This will be modified in the next publication on this work.) The table torque command is set to $0 \mathrm{~N}-\mathrm{m}$ throughout these tests.

Figure 8 shows the total flywheel current following the step change in the charging current command. It also shows the source current transitioning to zero and the flywheel current going negative to supply the entire load as the system moves from charge to discharge mode. A negative system flywheel current indicates that the flywheels are providing the power to the system; a positive flywheel current indicates that energy is being stored in the flywheels. Figure 14 gives the same information for the experimental case.

Figures 9 and 15 show the split in the total flywheel system current between the two flywheels, HSS and D1. In the experimental case (Figure 15) the HSS and D1 currents are practically equal so that one masks the other in the plot. Figure 10 shows the voltage change from the charge value of 125 volts to the flywheel regulated discharge value of 120 volts. It can be seen that there is a slight voltage transient when the power load is increased at point "c". Figure 15 is the corresponding figure for the experimental case.

Figure 11 shows the flywheel rotor speeds. It can be seen that the HSS flywheel decelerates much more quickly than the D1 flywheel to provide the required power to the load while maintaining 0 torque on the table as seen in Figure 12. Figures 17 and 18 are the corresponding experimental results.

Finally, Figure 13 shows the D1 motor phase current envelope for simulation and Figure 19 is the corresponding experimental plot. These plots demonstrate the functionality of the control in the charge and discharge modes with a zero torque command on the table.

\section{Test 2}

The next set of data demonstrates the functionality of the control in charge mode with a step change in the table torque. The Test 2 simulation results are presented in Figures 20 through 25 and experimental results are given in Figures 26 through 31 . A step change in the charging current command is given at point "a", then a torque step command of $+0.5 \mathrm{~N}-\mathrm{m}$ is given at point " $\mathrm{b}$ ", and at point "c" the torque command is returned to 0 . (The step change in current command at point "a" is not shown in the experimental results.)

Figure 20 shows the total flywheel current in charge mode during a step change in the table torque command. Figure 26 presents the corresponding experimental results. In both plots, it can be seen that a step change in the table torque results in a disturbance to the flywheel charging current.
The action of the PI control in the charge mode portion of the power controller (Fig. 3) is seen to bring the flywheel current back toward the commanded value. This disturbance is caused by an inaccurate $\mathbb{P}_{\mathrm{dc}}^{*}$ command to the attitude control and bus regulation algorithm. The control algorithm is modified to correct this in the results presented in the Section 5.

Figures 21 and 27 show the individual flywheel currents during the torque step command for simulation and experimental results respectively. It can be seen that the HSS is discharging (negative DC current) while the D1 unit is charging (positive DC current) to exchange the correct amount of momentum to apply the commanded torque to the table. Figures 23 and 29 also show the exchange of momentum between the HSS and D1 because HSS is decelerating (discharging) while D1 is accelerating (charging).

Figures 24 and 30 show the table torque response to the step change command. Both simulation and experimental results show the torque following the commanded value with the expected dynamic response of the air table and load cell.

Finally, figures 25 and 31 show the D1 motor phase current during the transitions.

\section{Test 3}

This set of data demonstrates the functionality of the control in discharge mode with a step change in torque. To demonstrate torque control in both the positive and negative directions, a negative torque command is given for this case. The Test 3 results are presented in Figures 32 through 37 for simulation and Figures 38 through 43 for the experimental results. Point "a" corresponds to a step change in the charging current command, point " $b$ " is the transition from charge mode to discharge mode, and point "c" is the torque step from 0 to $-0.5 \mathrm{~N}-\mathrm{m}$. (Again, the step change in current command at point " $\mathrm{a}$ " is not shown in the experimental results.)

Figures 32 and 38 present the DC currents for simulation and experimental results respectively. The total flywheel current becomes negative when the system moves into discharge mode. Figures 33 and 39 show the individual flywheel currents during the torque step command for simulation and experimental results respectively. The HSS DC current is positive for a negative torque step and the D1 current is negative indicating that the HSS flywheel is charging while the D1 flywheel is discharging.

Figures 35 and 41 show the corresponding flywheel speeds for simulation and experimental results respectively. Both flywheels initially start out discharging, but when the torque step is commanded, the HSS accelerates while the D1 unit discharges more quickly to provide both the electrical power and momentum transfer to the HSS necessary to meet the $0.5 \mathrm{Nm}$ torque command. 


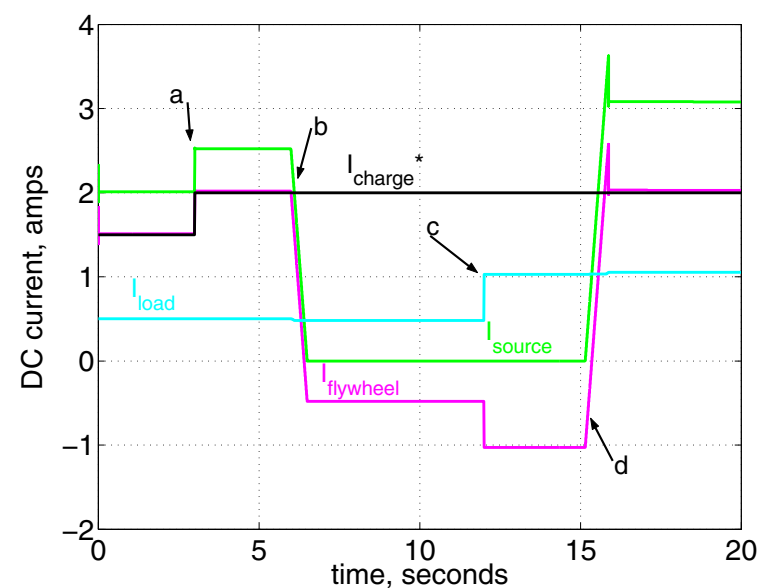

Figure 8.-Source, Load and Total Flywheel System DC Currents for Test 1 Simulation

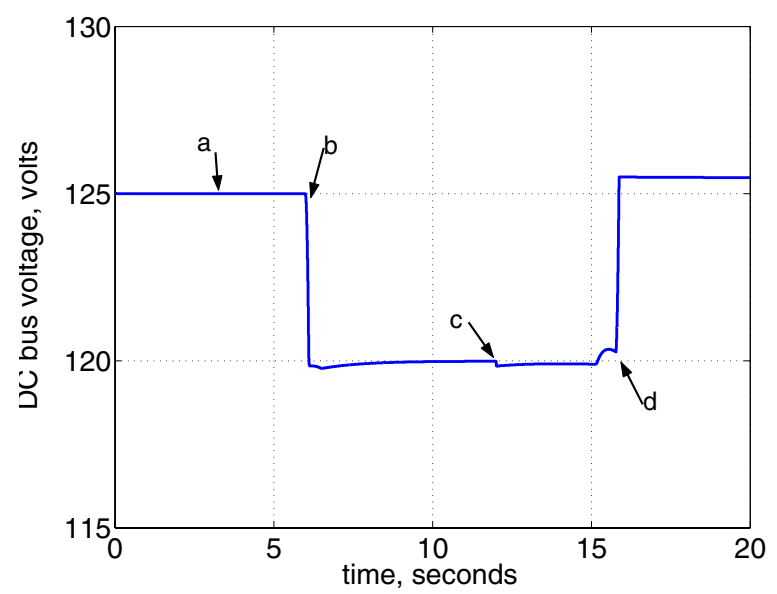

Figure 10.—DC Bus Voltage for Test 1 Simulation

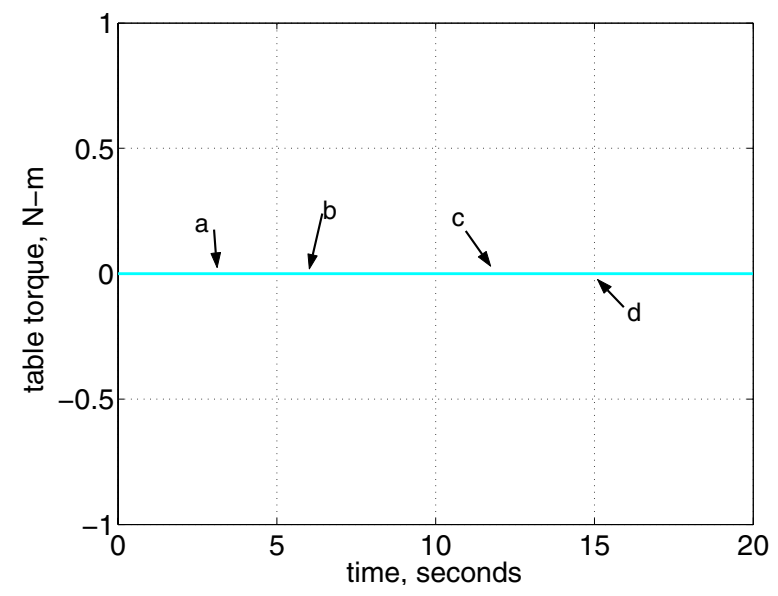

Figure 12.-Table Torque for Test 1 Simulation

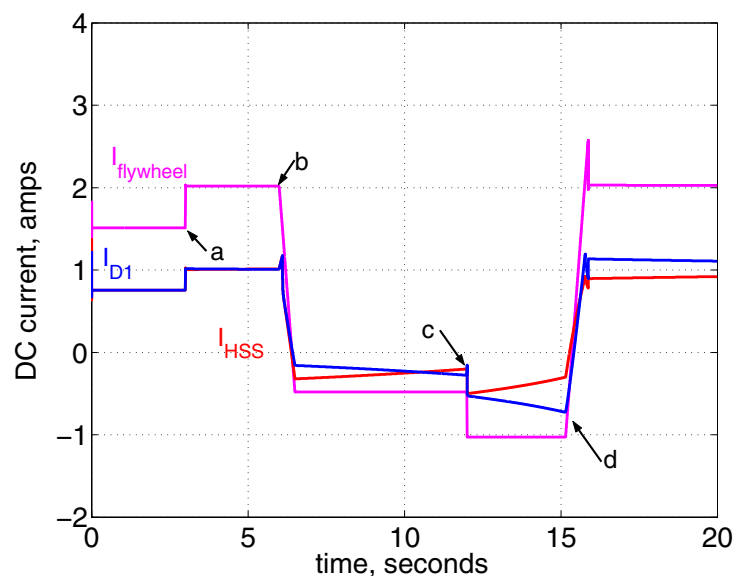

Figure 9.-D1 Flywheel, HSS Flywheel and Total Flywheel System DC Currents for Test 1 Simulation

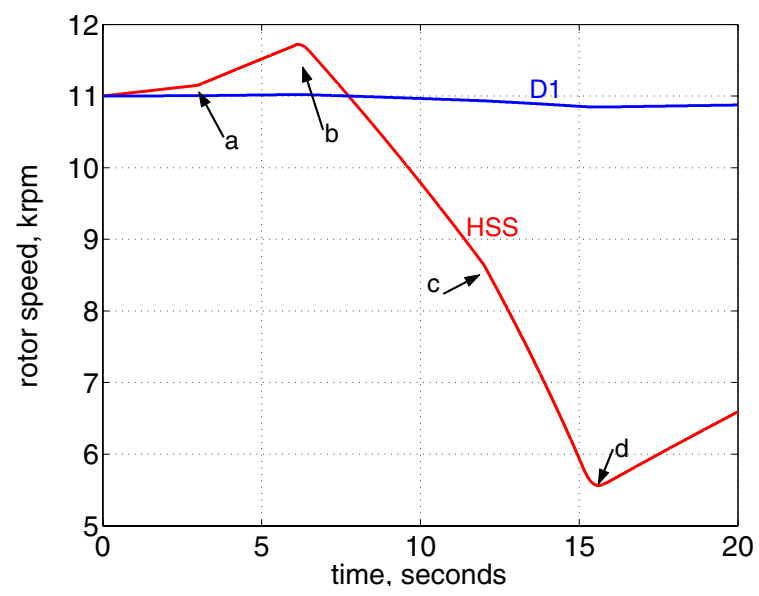

Figure 11.-Flywheel Rotor Speeds for Test 1 Simulation

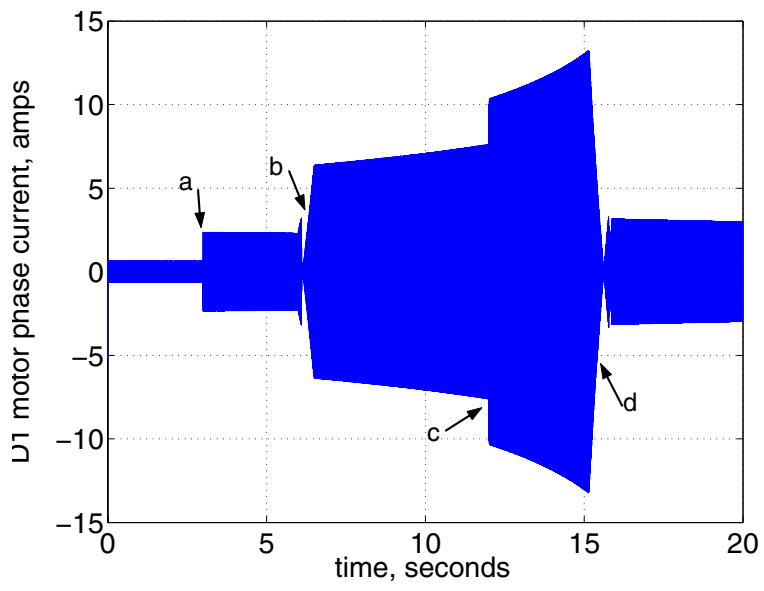

Figure 13.-D1 Motor Phase Current for Test 1 Simulation 


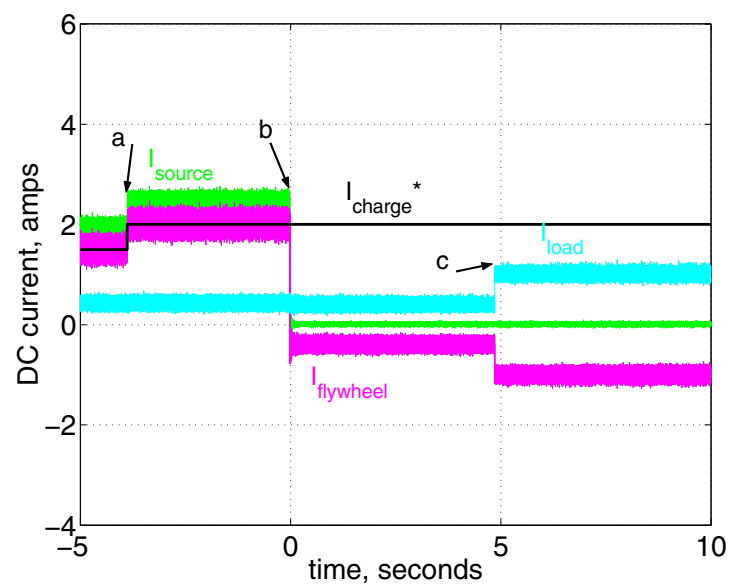

Figure 14.- Source, Load and Total Flywheel System DC Currents for Test 1 Experimental Results

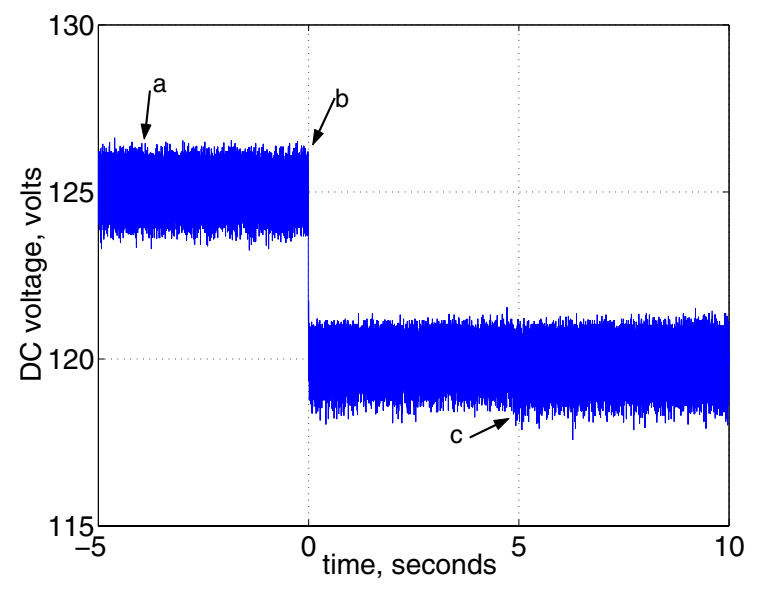

Figure 16. -DC Bus Voltage for Test 1 Experimental Results

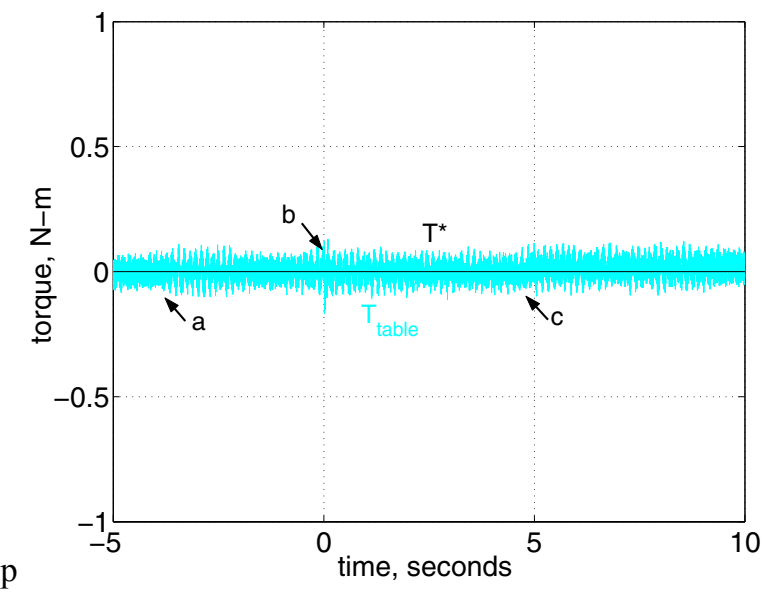

Figure 18.-Table Torque for Test 1 Experimental Results

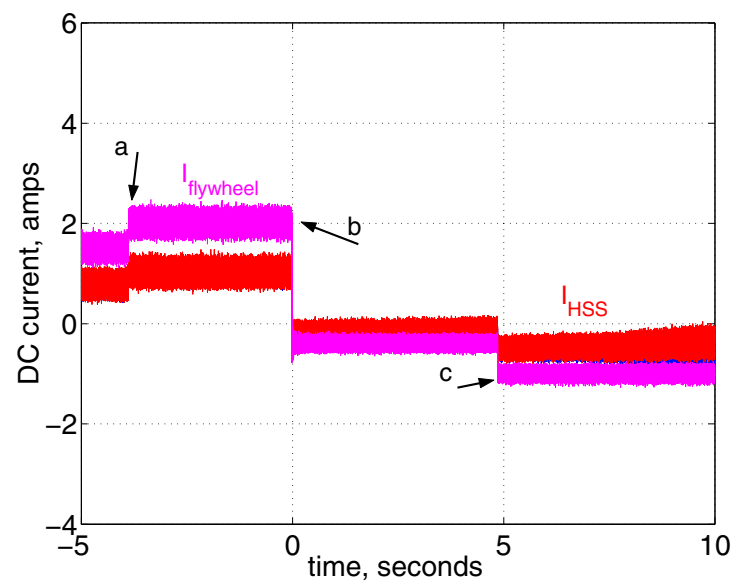

Figure 15.-D1 Flywheel, HSS Flywheel and Total Flywheel System DC Currents for Test 1 Experimental Results

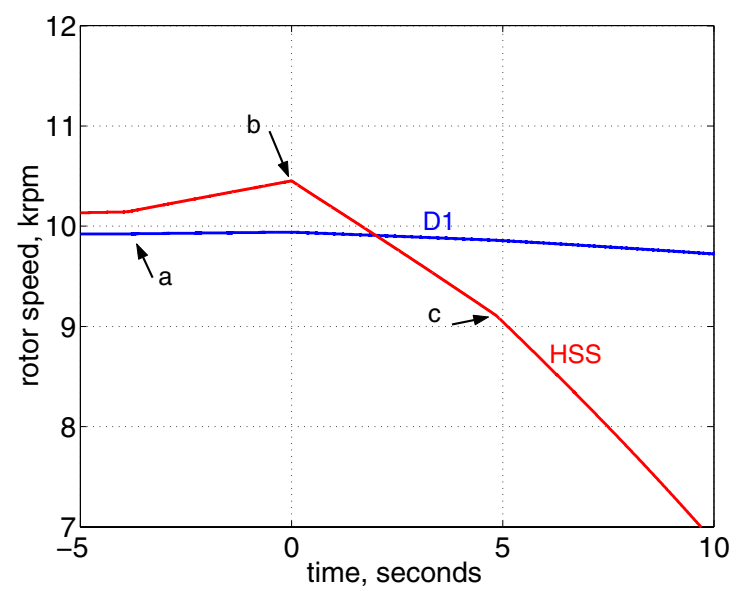

Figure 17.-Flywheel Rotor Speeds for Test 1 Experimental Results

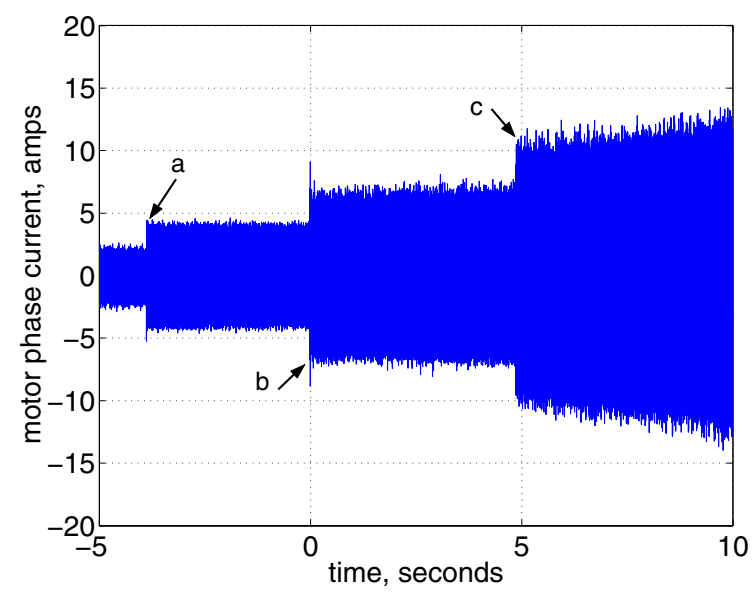

Figure 19.-D1 Motor Phase Current for Test 1 Experimental Results 


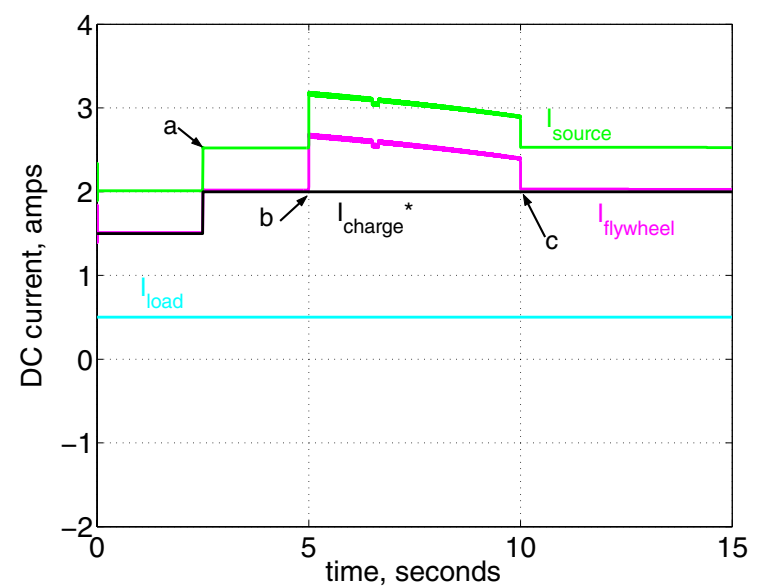

Figure 20.- Source, Load and Total Flywheel System DC Currents for Test 2 Simulation

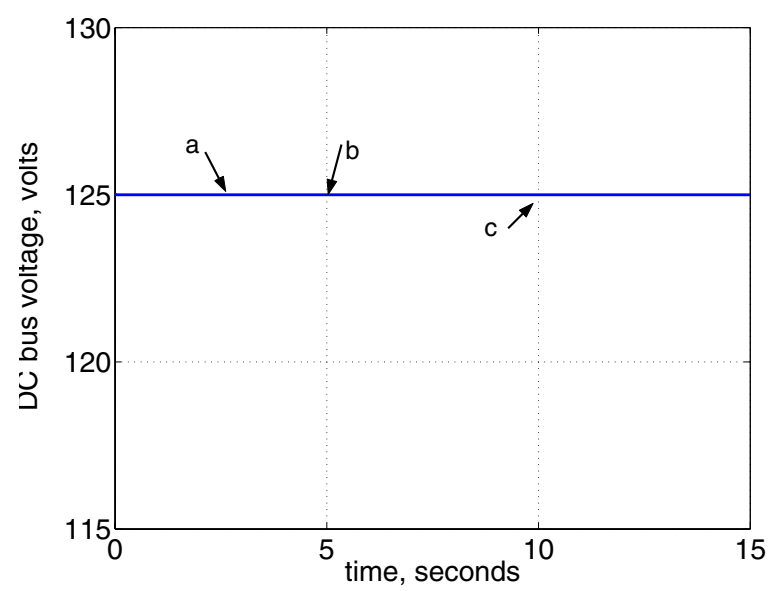

Figure 22.-DC Bus Voltage for Test 2 Simulation

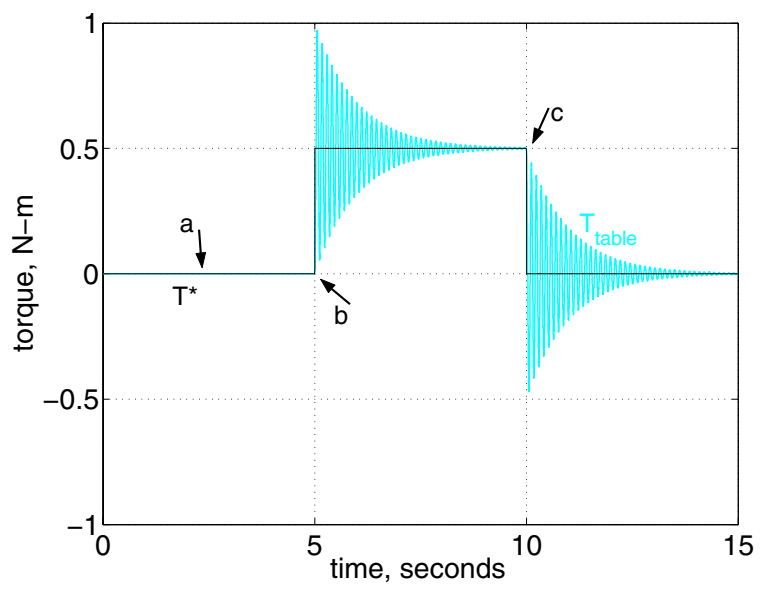

Figure 24.-Table Torque for Test 2 Simulation

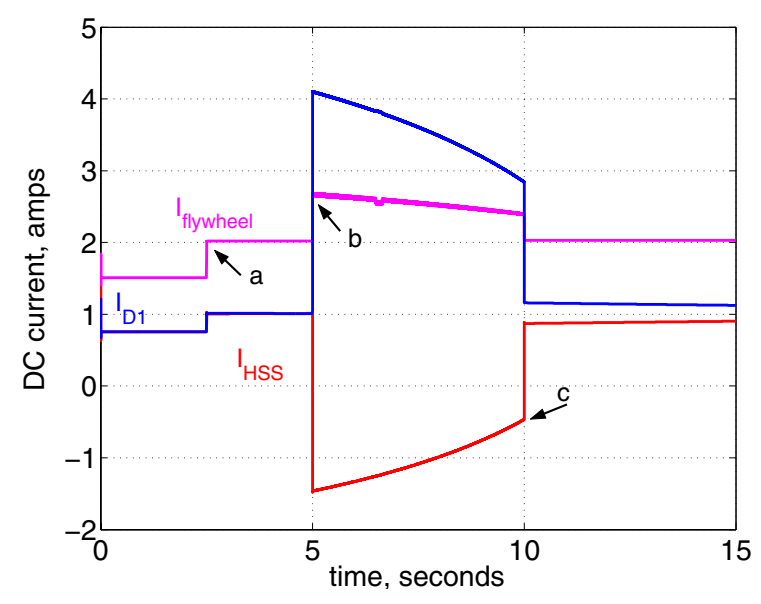

Figure 21.-D1 Flywheel, HSS Flywheel and Total Flywheel System DC Currents for Test 2 Simulation

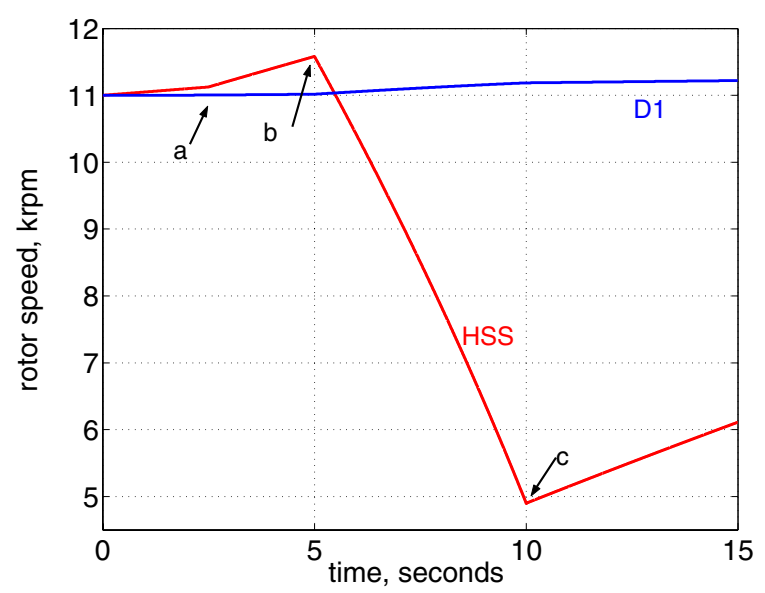

Figure 23.-Flywheel Rotor Speeds for Test 2 Simulation

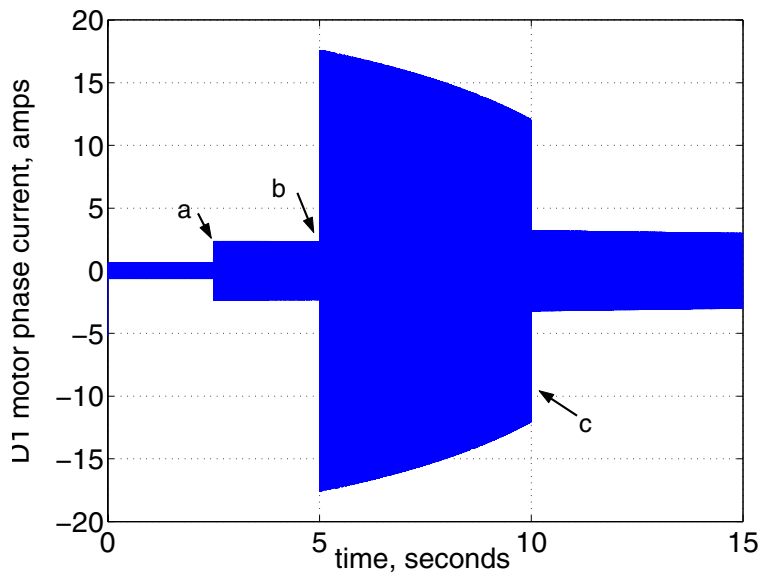

Figure 25.-D1 Motor Phase Current for Test 2 Simulation 


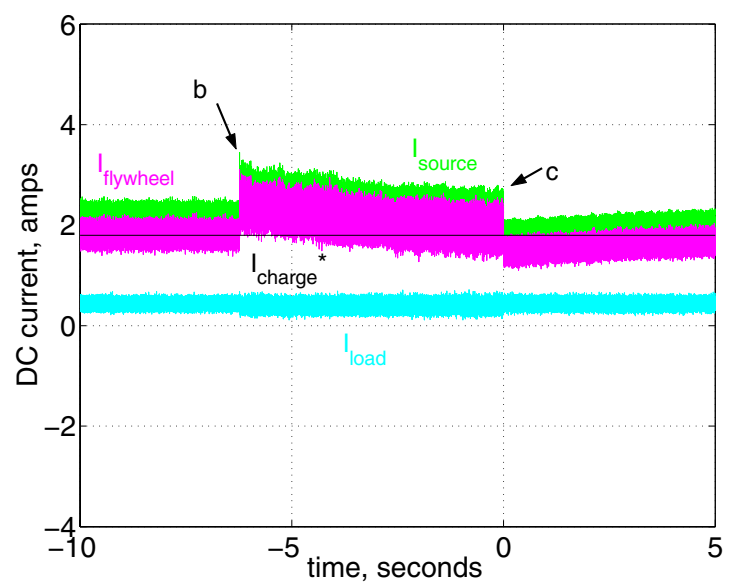

Figure 26.--Source, Load and Total Flywheel System DC Currents for Test 2 Experimental Results

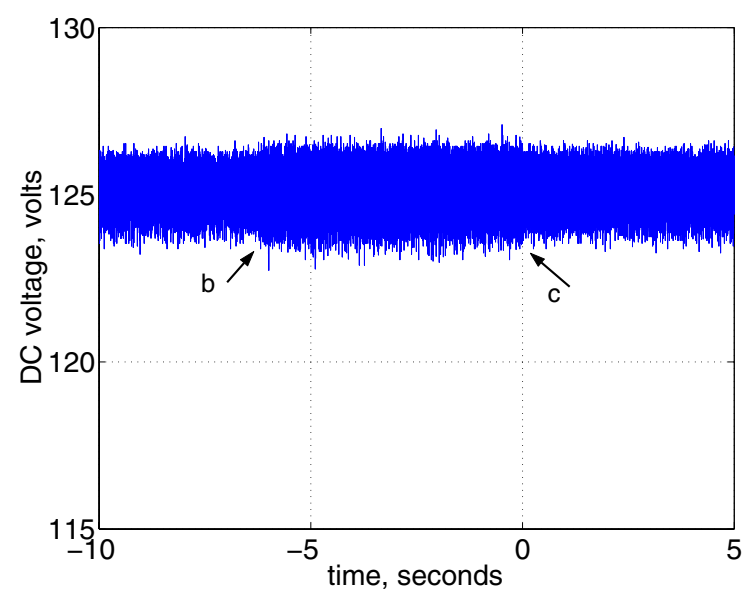

Figure 28.-DC Bus Voltage for Test 2 Experimental Results

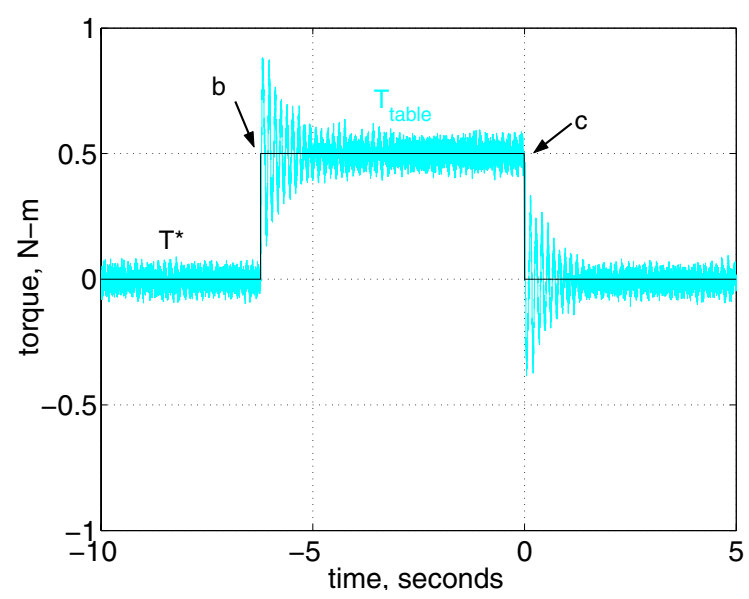

Figure 30.-Table Torque for Test 2 Experimental Results

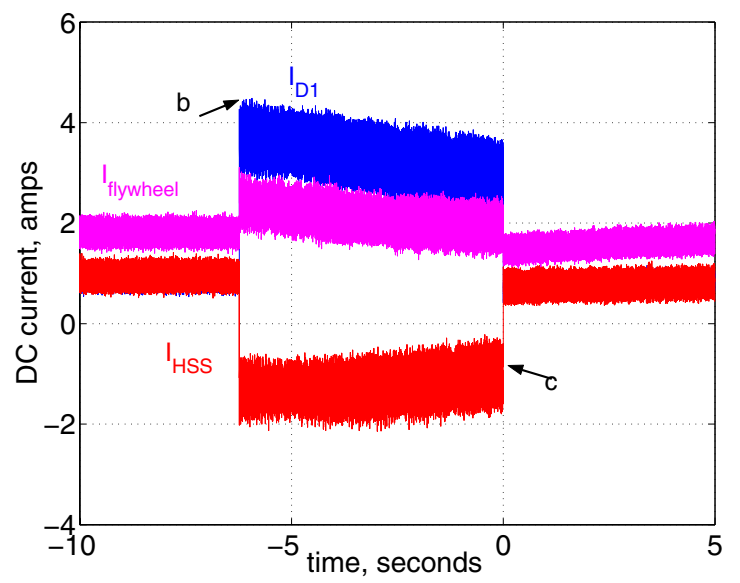

Figure 27.-D1 Flywheel, HSS Flywheel and Total Flywheel System DC Currents for Test 2 Experimental Results

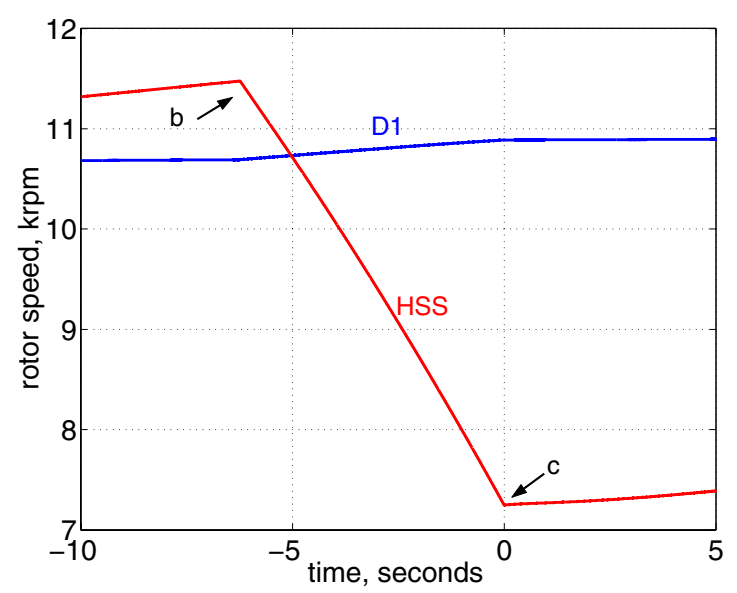

Figure 29.-Flywheel Rotor Speeds for Test 2 Experimental Results

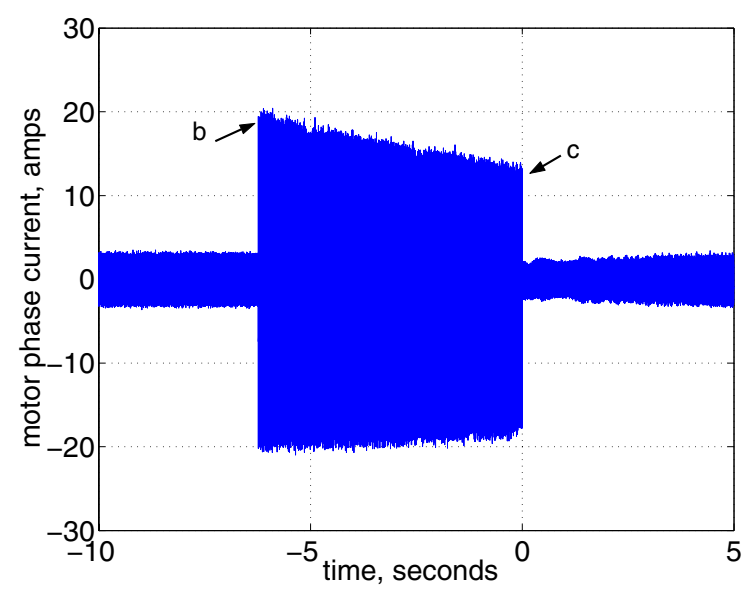

Figure 31.-D1 Motor Phase Current for Test 2 Experimental Results 


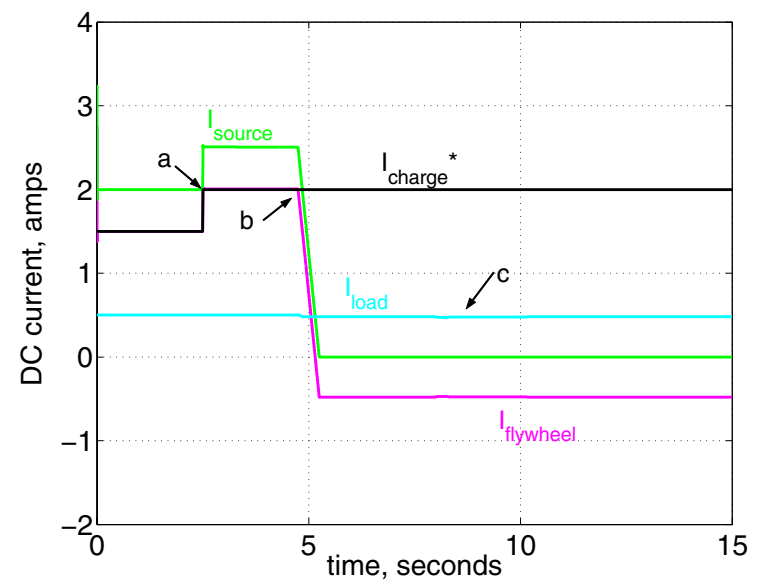

Figure 32.- Source, Load and Total Flywheel System DC Currents for Test 3 Simulation

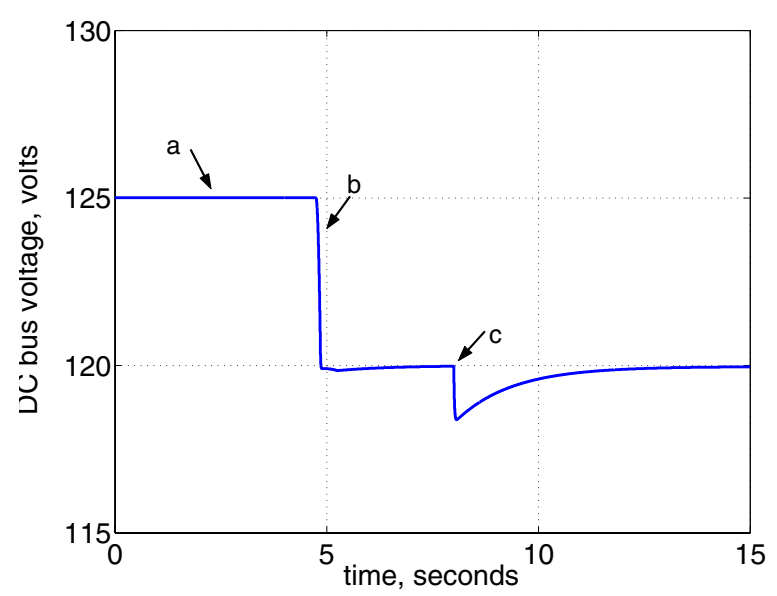

Figure 34.-DC Bus Voltage for Test 3 Simulation

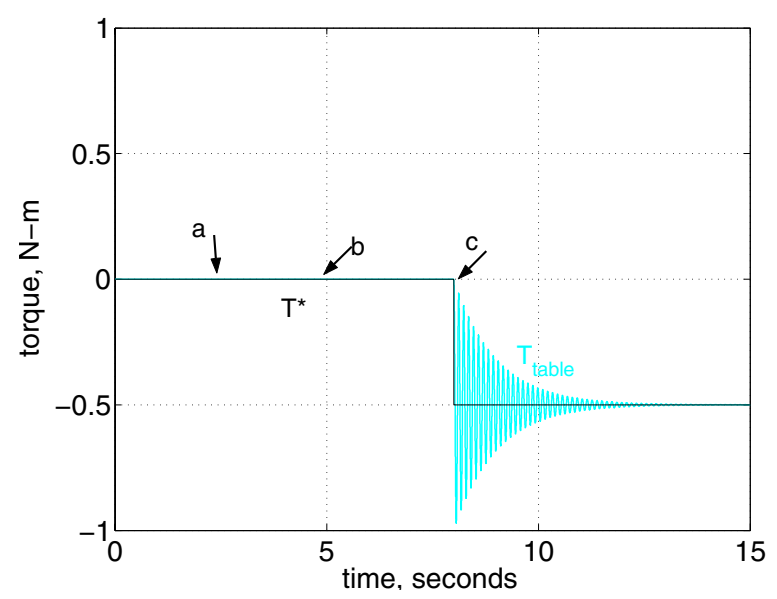

Figure 36.-Table Torque for Test 3 Simulation

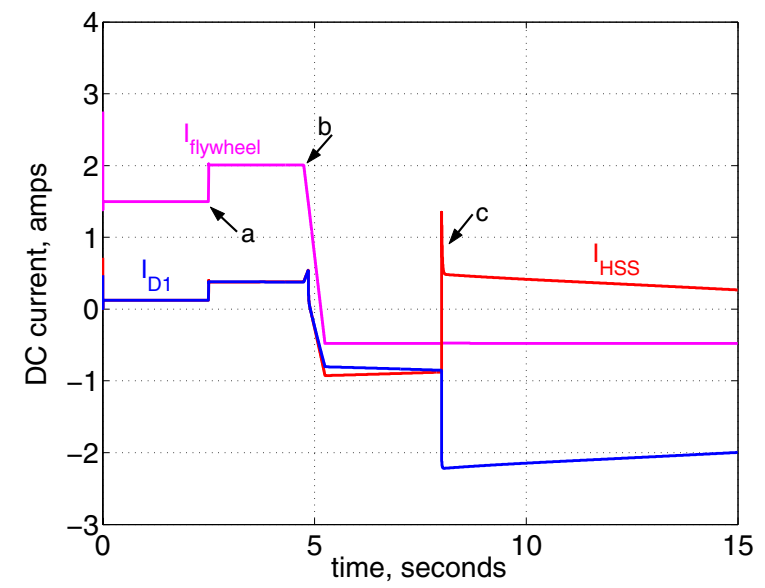

Figure 33.-D1 Flywheel, HSS Flywheel and Total Flywheel System DC Currents for Test 3 Simulation

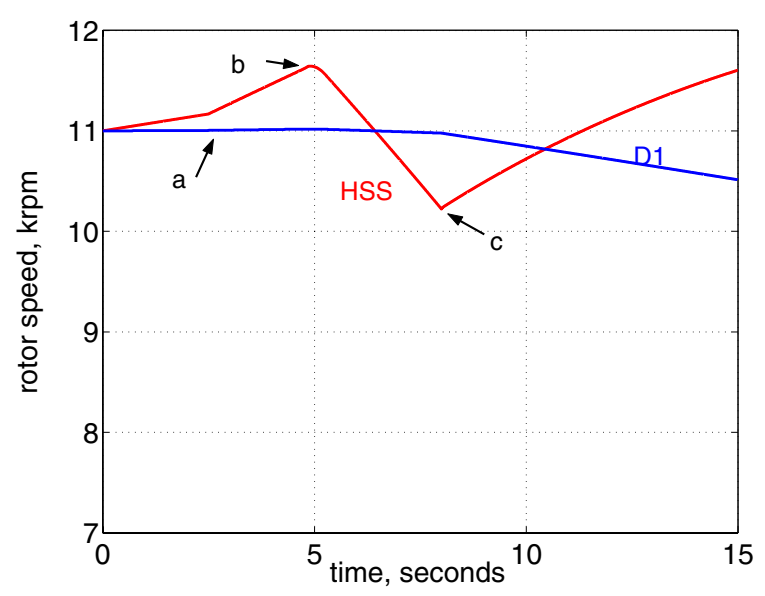

Figure 35.-Flywheel Rotor Speeds for Test 3 Simulation

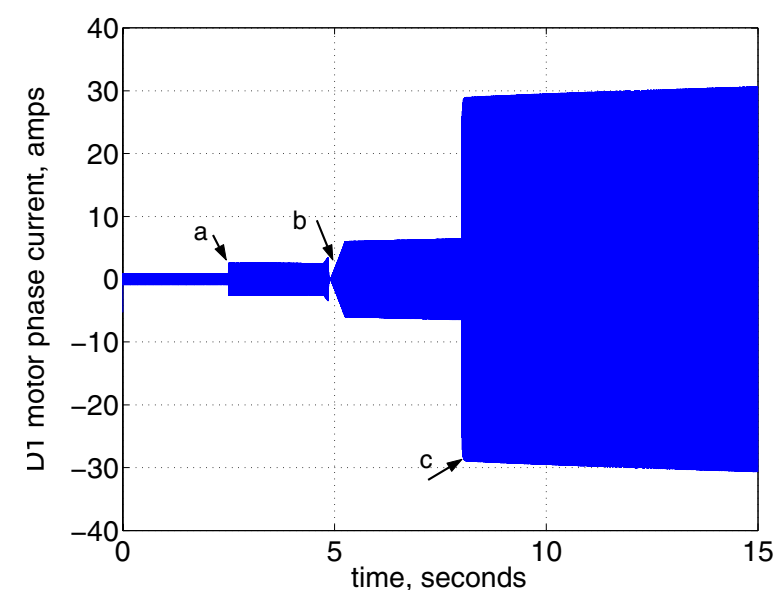

Figure 37.-D1 Motor Phase Current for Test 3 Simulation 


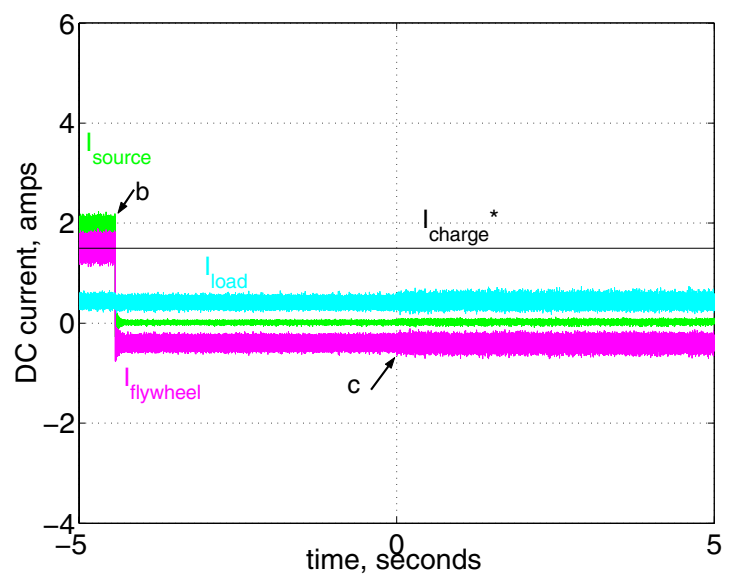

Figure 38.- Source, Load and Total Flywheel System DC Currents for Test 3 Experimental Results

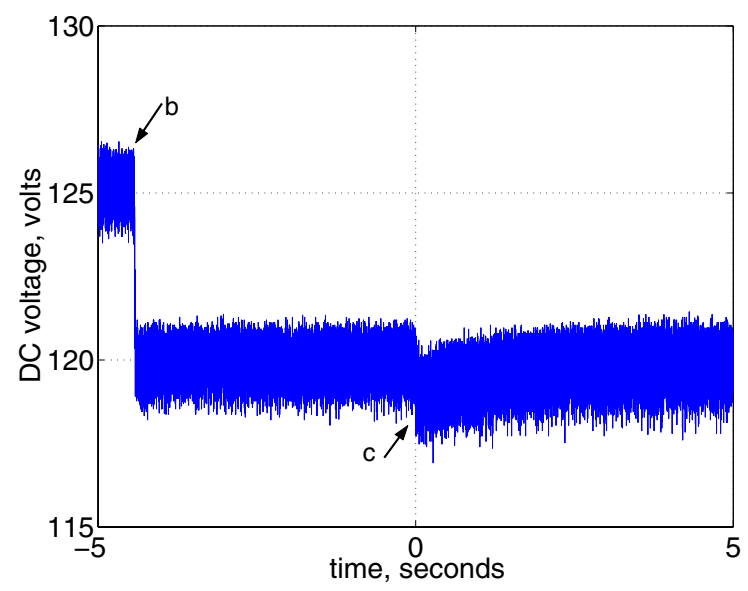

Figure 40.-DC Bus Voltage for Test 2 Experimental Results

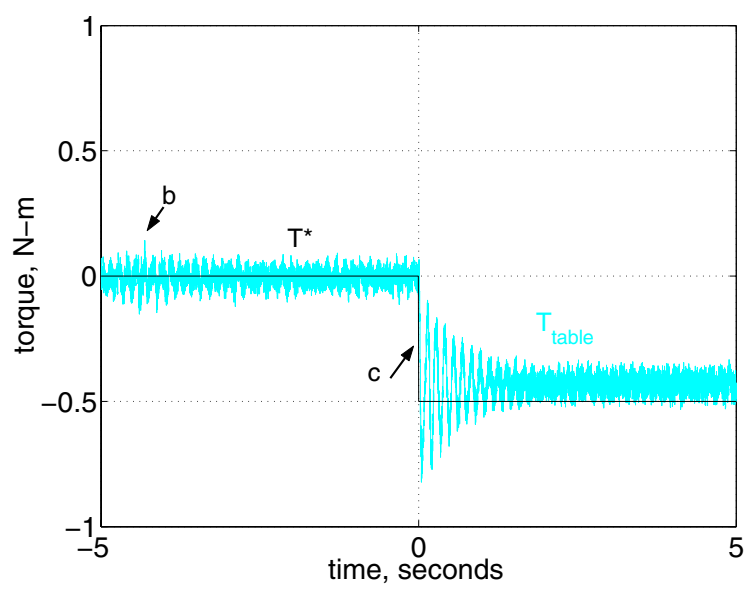

Figure 42.-Table Torque for Test 3 Experimental Results

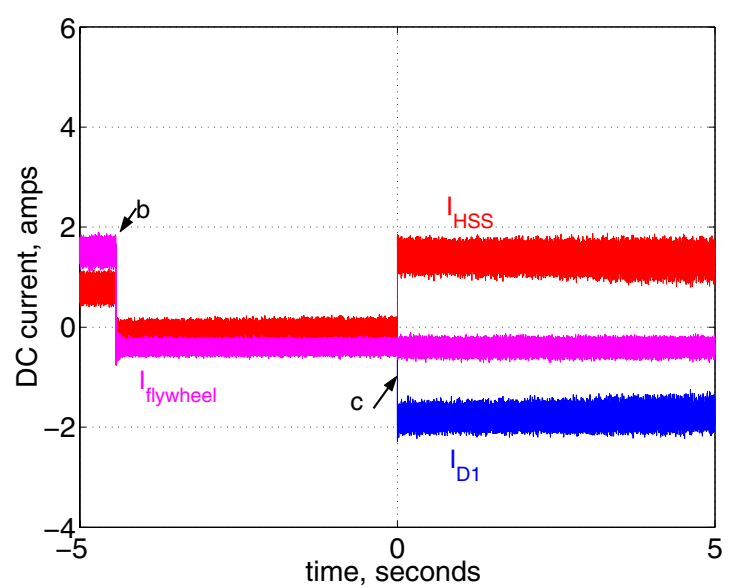

Figure 39.-D1 Flywheel, HSS Flywheel and Total Flywheel System DC Currents for Test 3 Experimental Results

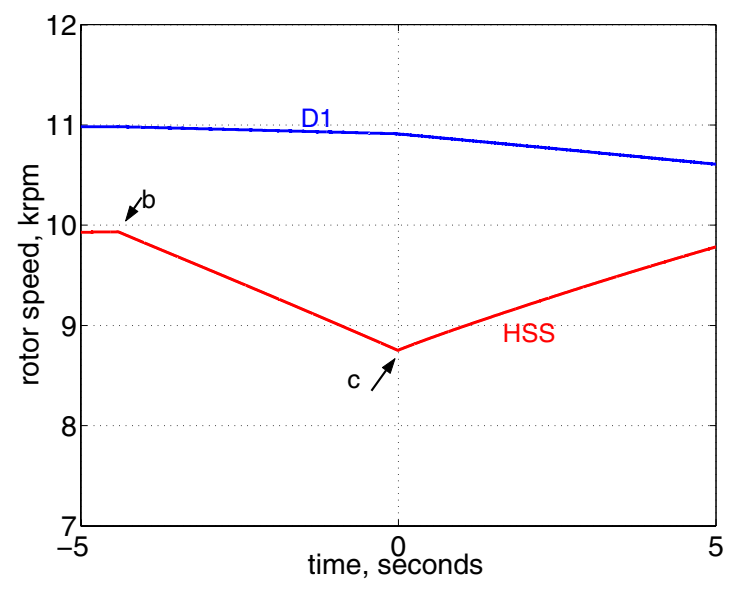

Figure 41.-Flywheel Rotor Speeds for Test 2 Experimental Results

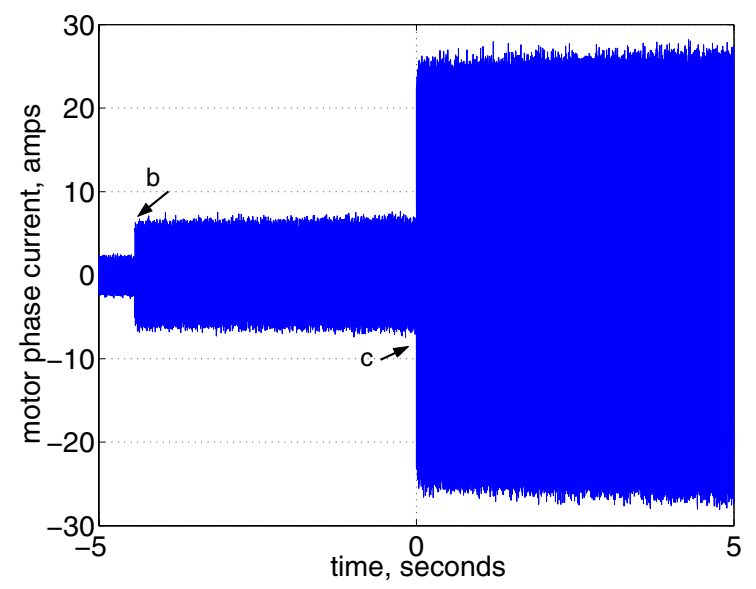

Figure 43.-D1 Motor Phase Current for Test 3 Experimental Results 
Figures 34 and 40 show the DC bus voltage. The torque step occurs while the system is in discharge mode (the flywheel system is regulating the DC bus) and it can be seen that there is a disturbance on the bus voltage at the torque step. Similar to the Test 2 results, this occurs because an inaccurate $\mathbb{P}_{\mathrm{dc}}{ }^{*}$ command is given to the attitude control and bus regulation algorithm. This also is corrected by the control algorithm change presented in the next section.

Figures 36 and 42 show the table torque response to the step change command. In the simulation case, the torque follows the commanded value exactly. However, experimentally, a steady state error is observed. This could be caused by using the wrong motor parameters in the control equations, specifically the back EMF constants $\lambda_{\text {afD1 }}$ and $\lambda_{\text {afHSS }}$ could be somewhat inaccurate. This is investigated in Section 6.

Figures 37 and 43 show the D1 motor phase current envelope during the transitions.

This initial series of tests, demonstrated both in simulation and experimentally, shows the functionality of the controller through several different combinations of power modes and torque steps. Three discrepancies were noted: there was a disturbance in the charging current during charge mode when a torque step was applied, there was a disturbance in the bus voltage during discharge mode when a torque step was applied and the table torque did not reach the commanded negative value in the experimental results. The first two of these discrepancies, power disturbances due to torque steps, are addressed in the next section.

\section{SIMULATION AND EXPERIMENTAL RESULTS: PART B}

In this section, the effect of modifying the control algorithm to include the AC resistance neglected in (4) is investigated. It will be seen in both simulation and experimental results that the modification of the control algorithm improves the power bus disturbance rejection during torque steps in both charge and discharge modes of operation.

\section{Control Modification}

In the original derivation of the control, the steady state motor voltage was calculated from (5) which neglected the AC voltage drop across the motor resistance. This was because it is generally true that this drop is small relative to the back EMF term, $\omega_{\mathrm{r}} \lambda_{\mathrm{af}}$.

$$
\mathrm{v}_{\mathrm{qs}}^{\mathrm{r}} \approx \omega_{\mathrm{r}} \lambda_{\mathrm{af}}
$$

However, in this case, the $\mathrm{i}_{\mathrm{qs}}^{\mathrm{r}} \mathrm{R}_{\mathrm{s}}$ term represents not only the voltage drop across the motor/generator resistance, but also the drop across the inverter switches, the AC filter and conductors leading to the machine. Neglecting it in this case turned out to unexpectedly lead to a disturbance in either the charging current (charge mode) or DC bus voltage (discharge mode) during a step change in the motor torque. The revised equation for the $\mathrm{AC}$ power to include the resistive drop is given in (13).

$$
\mathbb{P}_{\mathrm{AC}} \approx \frac{3}{2} \mathrm{i}_{\mathrm{qs}}^{\mathrm{r}}\left(\omega_{\mathrm{r}} \lambda_{\mathrm{af}}+\mathrm{i}_{\mathrm{qs}}^{\mathrm{r}} \mathrm{R}_{\mathrm{s}}\right)
$$

The approximate total DC power then becomes

$$
\begin{gathered}
\mathbb{P}_{\text {DCtotal }} \approx \mathbb{P}_{\mathrm{AC} 1}+\mathbb{P}_{\mathrm{AC} 2}= \\
\frac{3}{2} \mathrm{i}_{\mathrm{qs} 1}^{\mathrm{r}}\left(\omega_{\mathrm{r} 1} \lambda_{\mathrm{af} 1}+\mathrm{i}_{\mathrm{qs} 1}^{\mathrm{r}} \mathrm{R}_{\mathrm{s} 1}\right)+\frac{3}{2} \mathrm{i}_{\mathrm{qs} 2}^{\mathrm{r}}\left(\omega_{\mathrm{r} 2} \lambda_{\mathrm{af} 2}+\mathrm{i}_{\mathrm{qs} 2}^{\mathrm{r}} \mathrm{R}_{\mathrm{s} 2}\right) .
\end{gathered}
$$

This expression is then combined with (1) and (7) to form the relationship between the DC power, the table torque and the motor currents as shown in (15).

$$
\begin{gathered}
{\left[\begin{array}{c}
\tau_{\text {table }} \\
P_{\mathrm{dc}}
\end{array}\right]=} \\
{\left[\begin{array}{c}
-\frac{3 \mathrm{P}_{1} \lambda_{\mathrm{af} 1}}{4} \\
\frac{3}{2}\left(\omega_{\mathrm{r} 1} \lambda_{\mathrm{af} 1}+\mathrm{i}_{\mathrm{qs} 1}^{\mathrm{r}} \mathrm{R}_{\mathrm{s} 1}\right) \frac{3}{2}\left(\omega_{\mathrm{r} 2} \lambda_{\mathrm{af} 2}+\mathrm{i}_{\mathrm{qs} 2}^{\mathrm{r}} \mathrm{R}_{\mathrm{s} 2}\right)
\end{array}\right]\left[\begin{array}{c}
\mathrm{i}_{\mathrm{qs} 1}^{\mathrm{r}} \lambda_{\mathrm{af} 2} \\
\mathrm{i}_{\mathrm{qs} 2}^{\mathrm{r}}
\end{array}\right]}
\end{gathered}
$$

It can be seen that the inclusion of the resistance term leads to a nonlinear expression relating the control variables, the motor currents, to the desired values of table torque and DC bus power. Thus it becomes more difficult to determine the commanded motor current values from the desired values of table torque and DC bus power. One approach to solving this is to linearize (14) about an operating point defined by the measured values of currents and then use the linearized equation in conjunction with equations (1) and (7) to form the matrix expression.

However, the approach used in this case is to use the matrix expression given in (15) with the modification shown below. The $\mathrm{i}_{\mathrm{qs}}^{\mathrm{r}}$ values used in the matrix now represent the measured $\left(\mathrm{i}_{\mathrm{qs}}^{\mathrm{rM}}\right)$ values fed back from the current sensors on the motor phases and the $\mathrm{i}_{\mathrm{qs}}^{\mathrm{r}}$ values used in the vector are the commanded $\left(\mathrm{i}_{\mathrm{qs}}^{\mathrm{r}^{*}}\right)$ ones. This is shown in (16).

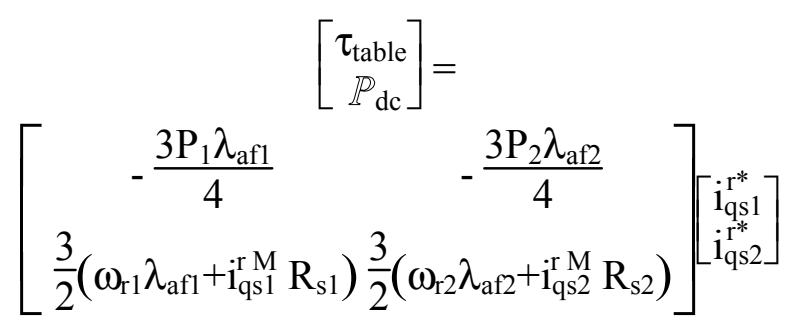

Equation (16) is solved for the commanded currents as shown in (17). The result given in (17) is almost identical to the linearized solution, however, it is easier and more intuitive to implement. 


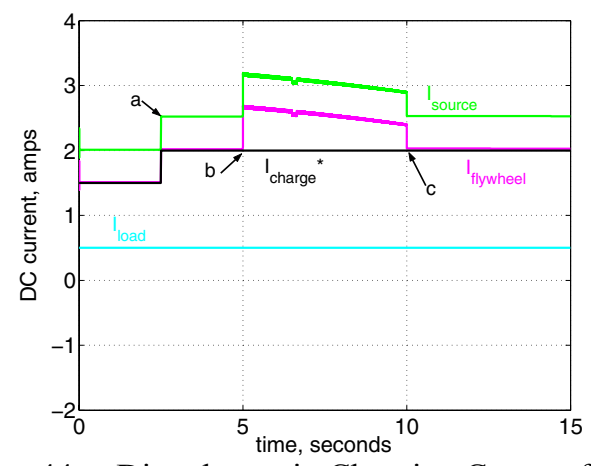

Figure 44.-Disturbance in Charging Current for Step

Change in Table Torque with Original Control

(eq. (12)), Simulation Results

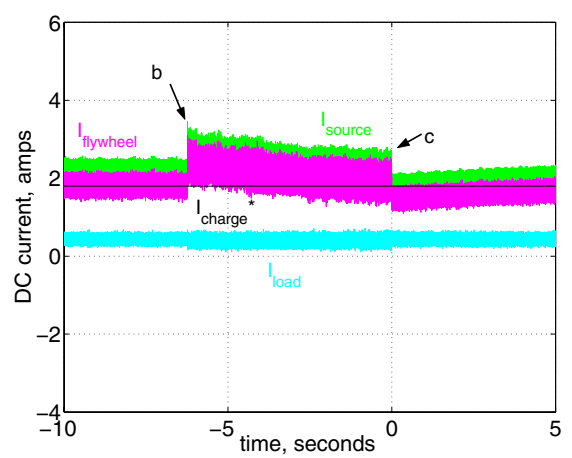

Figure 46.-Disturbance in Charging Current for Step

Change in Table Torque with Original Control (eq. (12)), Experimental Results

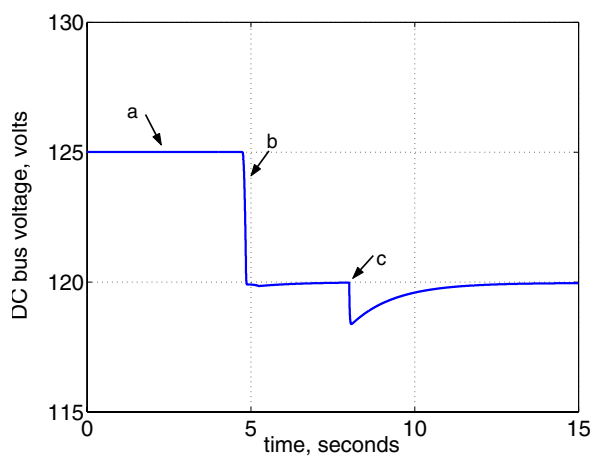

Figure 48.-Disturbance in DC Bus Voltage for Step Change in Table Torque with Original Control (eq. (12)), Simulation Results

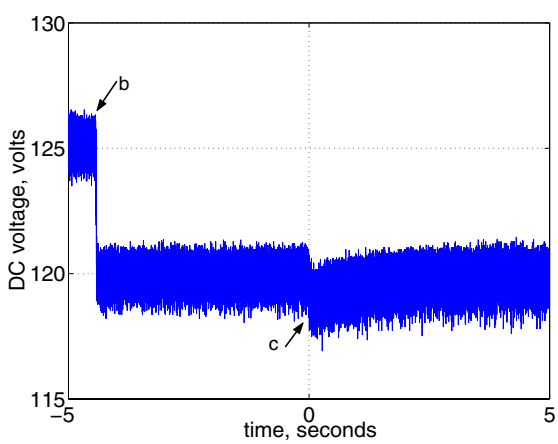

Figure 50.-Disturbance in DC Bus Voltage for Step Change in Table Torque with Original Control (eq. (12)), Experimental Results

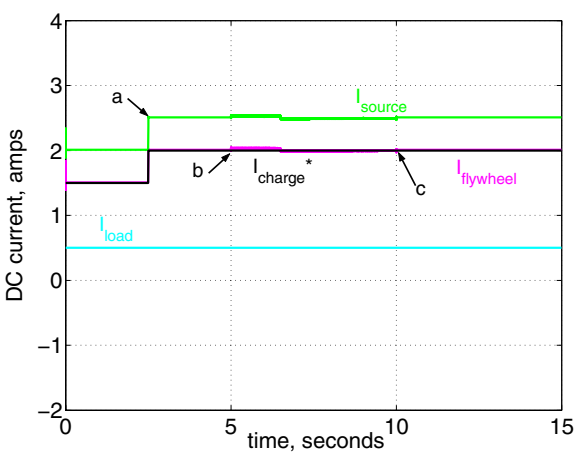

Figure 45.-Charging Current for Step Change in Table Torque with Modified Control (eq. (17)), Simulation Results

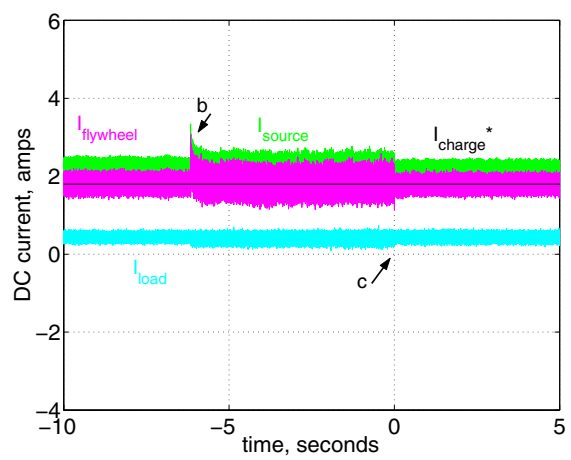

Figure 47.-Charging Current for Step Change in Table Torque with Modified Control (eq. (17)),

Experimental Results

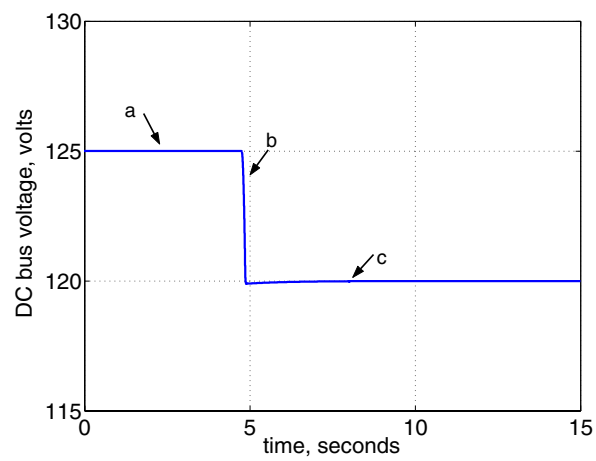

Figure 49.-DC Bus Voltage for Step Change in Table Torque with Modified Control (eq. (17)), Simulation Results

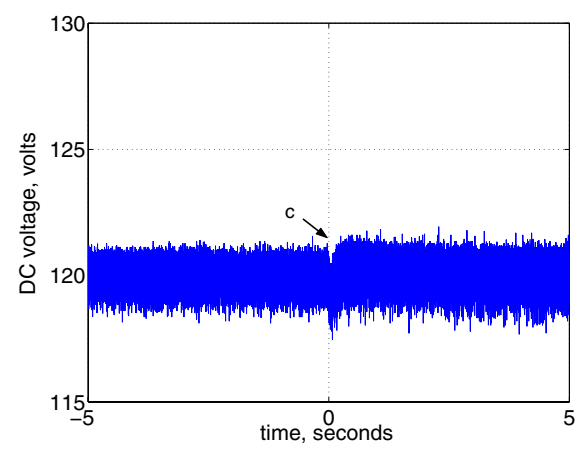

Figure 51.-DC Bus Voltage for Step Change in Table Torque with Modified Control (eq. (17)), Experimental Results 


$$
\begin{gathered}
{\left[\begin{array}{c}
\mathrm{i}_{\mathrm{qs} 1}^{\mathrm{r}} \\
\mathrm{i}_{\mathrm{qs} 2}^{\mathrm{r}}
\end{array}\right]=} \\
\frac{2}{3\left[\mathrm{P}_{2} \lambda_{\mathrm{af} 2}\left(\omega_{1} \lambda_{\mathrm{af} 1}+\mathrm{i}_{\mathrm{qs} 1}^{\mathrm{r} \mathrm{M}} \mathrm{R}_{\mathrm{s} 1}\right)-\mathrm{P}_{1} \lambda_{\mathrm{af} 1}\left(\omega_{2} \lambda_{\mathrm{af} 2}+\mathrm{i}_{\mathrm{qs} 2}^{\mathrm{r} \mathrm{M}} \mathrm{R}_{\mathrm{s} 2}\right)\right]} \\
\mathrm{X}\left[\begin{array}{cc}
2\left(\omega_{2} \lambda_{\mathrm{af} 2}+\mathrm{i}_{\mathrm{qs} 2}^{\mathrm{r}} \mathrm{R}_{\mathrm{s} 2}\right) & \mathrm{P}_{2} \lambda_{\mathrm{af} 2} \\
-2\left(\omega_{1} \lambda_{\mathrm{af} 1}+\mathrm{i}_{\mathrm{qs} 1}^{\mathrm{r}} \mathrm{R}_{\mathrm{s} 1}\right) & \left.-\mathrm{P}_{1} \lambda_{\mathrm{af} 1}\right] \\
\mathbb{P}_{\mathrm{dc}}^{*}
\end{array}\right]
\end{gathered}
$$

To verify the improvement in the control by using the modified equations, the two torque step tests (Test 2 and 3) were repeated with the adjusted control. Test 2 is the case where the torque step occurs while in charge mode. Simulation and experimental results for the charging current during the torque step are shown in Figs. 44 through 47 with the previous results (without the control modification) shown also for comparison. It can be seen that the modification reduces the charging current disturbance significantly both in simulation and experimentally.

Test 3 is the case where the torque step occurs while the system is in discharge mode. Simulation and experimental results for the DC bus voltage during the torque step are shown in Figs. 48 through 51 , again with the original results repeated for comparison. It can be seen that the modification reduces the DC bus voltage disturbance significantly during the torque step transient.

\section{EXPERIMENTAl Results: PART C}

In this section, the cause of the steady state torque error observed experimentally for a negative step change in torque (Test 3, Fig. 42) is investigated. It is concluded that the error is not due to an error in the control algorithm or estimated motor parameters but rather is due to the mechanical characteristics of the load cell being used to measure the table torque.

To investigate the steady state torque error, Test 3 was conducted again (experimentally only because the error was not observed in simulation) but with each flywheel spinning in the opposite direction from the previous tests. In the Part A and Part B results presented in Sections 4 and 5, the D1 flywheel was tested while spinning in the clockwise (CW)

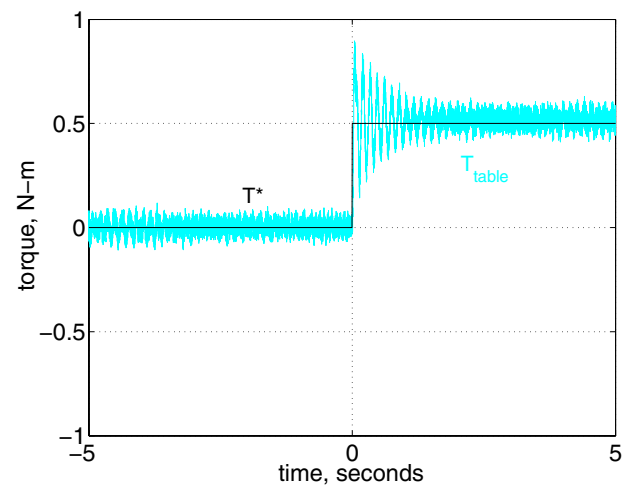

Figure 52.-Positive Torque Step for CW Rotation of HSS direction and the HSS flywheel was spinning in the counterclockwise (CCW) direction. The torque step experiment as repeated for D1 spinning in the CCW direction and HSS spinning in the CW direction. If the steady state error was due to a control algorithm problem or inaccurate estimate of the motor parameters, changing the spin direction should result in a steady state error for a positive torque step and no error for a negative step. That was not the case, as seen in Figures 52 through 59.

Figures 52 through 55 give the results for a positive step change in torque with the HSS spinning CW for Fig. 52 and 54 and CCW for Fig. 53 and 55. It can be seen that the positive step in torque exhibits no steady state error regardless of the direction of spin and whether the flywheels are accelerating or decelerating during the step.

Figures 56 through 59 give the results for a negative step change in torque with the HSS spinning CW for Fig. 56 and 58 and CCW for Fig. 57 and 59. In this case, there is a steady state error in the torque for either spin direction. The conclusion is that this error is due to the mechanical characteristics of the load cell and not due to any control inaccuracy.

\section{ConClusions}

The NASA Glenn Research Center has experimentally demonstrated the feasibility of combined single axis attitude control and energy storage using two flywheels. Although the concept of combining attitude control and energy storage has been studied previously in the literature, this is the first experimental demonstration of such a system. Torque steps during charge and discharge modes and load (power) steps while maintaining DC bus regulation have all been demonstrated. Additionally, decoupled torque and power control was improved by modifying the original control to include the effects of resistive drops on the AC side of the system. The overall system control is accomplished by the integration of three techniques: a position sensorless field orientation algorithm for the inner loop motor control, a charge/discharge algorithm for power regulation and an outer loop control to simultaneously achieve commanded single axis torque and electrical power.

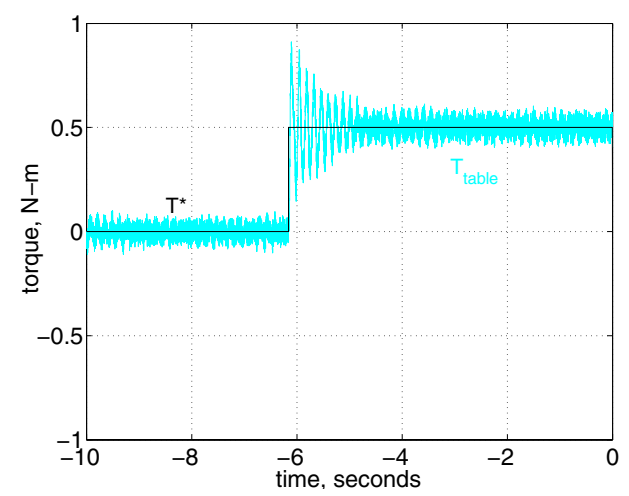

Figure 53.-Positive Torque Step for CCW Rotation of HSS 


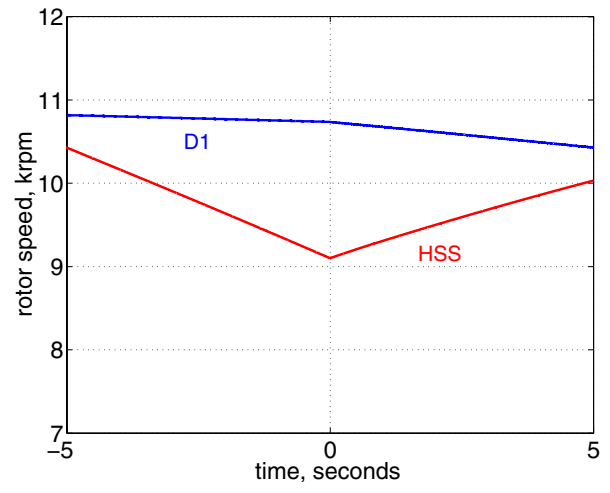

Figure 54.-HSS Accelerating During Torque Step

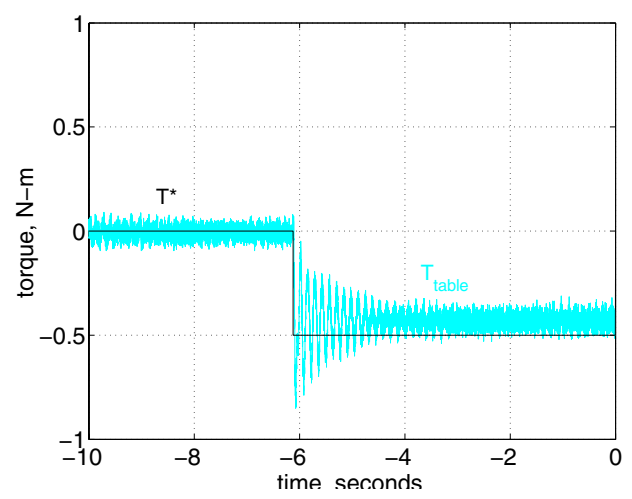

Figure 56.- Negative Torque Step for CW Rotation of HSS

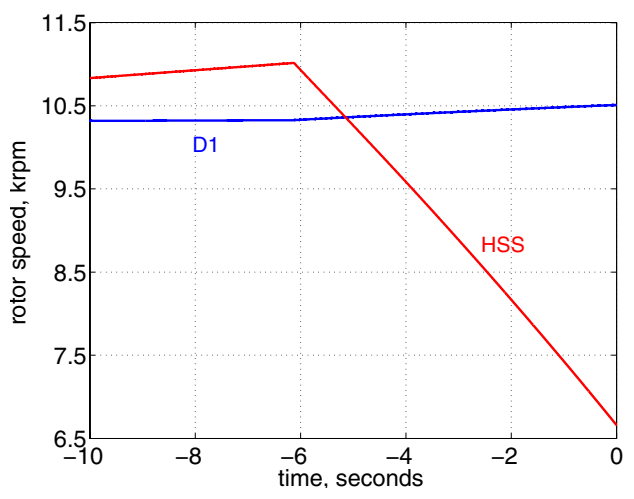

Figure 58.-HSS Decelerating During Torque Step

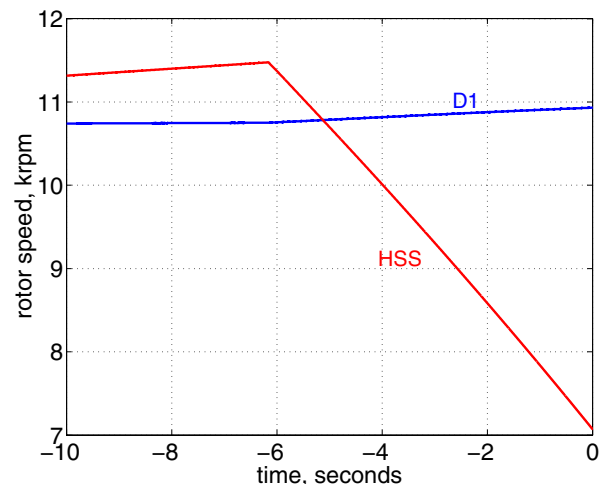

Figure 55.-HSS Decelerating During Torque Step

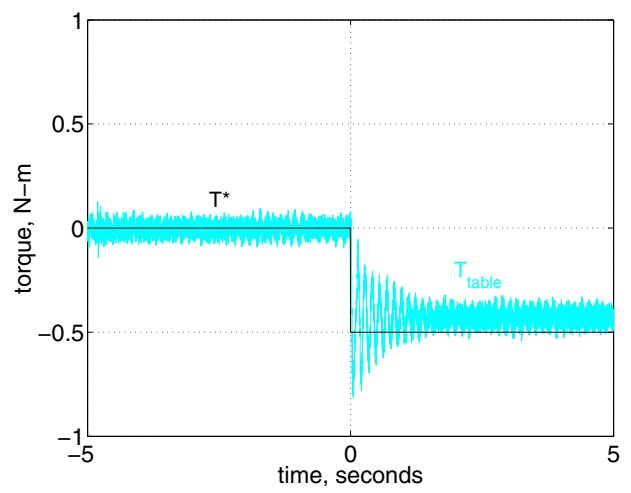

Figure 57.- Negative Torque Step for CCW Rotation of HSS

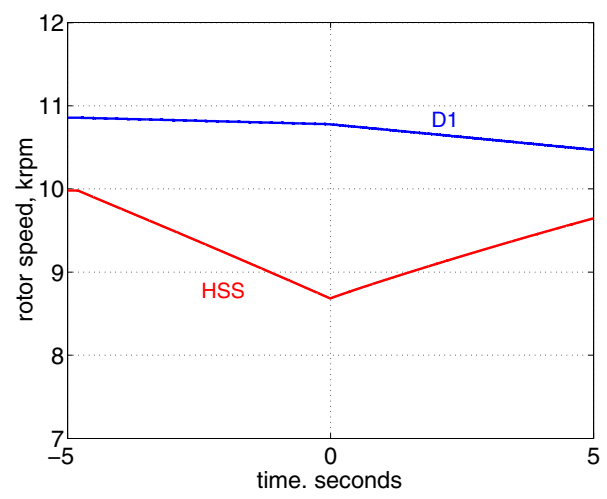

Figure 59.- HSS Accelerating During Torque Step 


\section{References}

1. Tsiotras, Panagiotis; Shen, Haijun; and Hall, Christopher, "Satellite Attitude Control and Power Tracking with Energy/Momentum Wheels". AIAA Journal of Guidance, Control and Dynamics, Vol. 24, No. 1, 2001, pp. 23-34.

2. Richie, David; Tsiotras, Panagiotis; Fausz, Jerry L., Simultaneous "Attitude control and Energy Storage using VSCMGs: Theory and Simulation". Proceedings of the American Control Conference, Arlington, VA., June 2527, 2001, pp. 3973-3979.

3. Hall, Christopher, "High Speed Flywheels for Integrated Energy Storage and Attitude Control". Proceedings of the American Control Conference, Albuquerque, NM., June, 1997, pp. 1894-1898.

4. Varatharajoo, Renuganth; Fasoulas, Stefanos, "Methodology for the Development of Combined Energy and Attitude Control Systems for Satellites", Aerospace Science and Technology 6, Vol. 6, No. 4, 2002, pp. 303311.

5. Kascak, Peter E.; Kenny, Barbara H.; Dever, Timothy; Santiago, Walter and Jansen, Ralph: "International Space Station Bus Regulation with NASA Glenn Research Center Flywheel Energy Storage System Development Unit." NASA TM 2001-211138, Proceedings of the 2001 Intersociety Energy Conversion Engineering Conference, Savannah, GA, July 29-Aug. 2, 2001.

6. Kenny, Barbara H.; Kascak, Peter E.: "DC Bus Regulation with a Flywheel Energy Storage System." NASA TM 2002-211897, SAE Paper 02PSC-61, Proceedings of the SAE Power Systems Conference, Coral Springs, FL, Oct. 29-31, 2002.

7. Kenny, Barbara H.; Kascak, Peter E.; Jansen, Ralph; Dever, Timothy; "A Flywheel Energy Storage System Demonstration for Space Applications." NASA TM 2003- 212346 Proceedings of the International Electric Machines and Drives Conference Madison, Wisconsin, June 1-4, 2003.

8. Kascak, Peter E., Jansen, Ralph, Kenny, Barbara H., Dever, Timothy, "Single Axis Attitude Control and DC Bus Regulation with Two Flywheels," NASA TM 2002-211812. Proceedings of the 2002 Intersociety Energy Conversion Engineering Conference, Washington,D.C., July 28-Aug. 2, 2002.

9. Ramu, Krishnan, Permanent magnet synchronous and brushless DC motor drives: theory, operation, performance, modeling, simulation, analysis and design, Virginia Polytechnical Institute, Blacksburg, Va., 1999.

10. Kenny, Barbara H.; Kascak, Peter E.; Hofmann, Heath; Mackin, Michael; Santiago, Walter and Jansen, Ralph: "Advanced Motor Control Test Facility for NASA GRC Flywheel Energy Storage System Technology Development Unit." NASA TM 2001-210986, Proceedings of the 2001 Intersociety Energy
Conversion Engineering Conference, Savannah, GA, July 29-Aug. 2, 2001.

11. Kenny, Barbara H.; Kascak, Peter E.: "Sensorless Control of Permanent Magnet Machine for NASA Flywheel Technology Development." NASA TM 2002211726, Proceedings of the 2002 Intersociety Energy Conversion Engineering Conference, Washington,D.C., July 28-Aug. 2, 2002.

12. Rowan, T. and R. Kerkman, "A New Synchronous Current Regulator and an Analysis of CurrentRegulated PWM Inverters", IEEE Transactions on Industry Applications, Vol IA-22, No. 4, July/August 1986, pp. 678-690.

\section{Biographies}

Barbara H. Kenny is an Electrical Engineer in the Electrical Systems Development Branch at the NASA Glenn Research Center, Cleveland, Ohio, where she has worked since 1989. She is involved in developing technology for the electrical power systems of advanced aircraft, spacecraft and launch vehicles. She is currently working to develop flywheel energy storage systems for space applications.

She received the B.S.E.E. from Cornell University in 1982, the M.S.E.E. from the University of Texas-- Austin in 1988 and the Ph.D. from the University of Wisconsin-- Madison in 2001. She is a registered Professional Engineer in Virginia. From 1982 to 1986 she was on active duty with the U.S. Air Force in facilities engineering. Her research interests include sensorless motor control for permanent magnet and induction machines, high speed machine design and control, and pulse width modulation techniques.

Dr. Kenny is a member of the Institute of Electrical and Electronic Engineering (IEEE) Industry Applications, Power Electronics, Aerospace and Electronic Systems, and Women in Engineering Societies.

Ralph Jansen is a Senior Research Associate with the University of Toledo, Toledo, Ohio where he has been employed since 2001 . He is currently leading a research effort to develop and test high speed flywheel energy storage systems for space applications. He began working on NASA programs as a summer intern in 1991 and became a full-time support service contractor with the Ohio Aerospace Institute in 1993. His work includes developing and testing magnetic bearings for flywheels and aircraft turbine engines.

Mr. Jansen received his B.S.M.E. in fluid and thermal engineering in 1991 and a M.S.M.E. in 1996, both from Case Western Reserve University. He is a member of the American Society of Mechanical Engineers (ASME) and the Society of Tribology and Lubrication Engineering (STLE). His research interests include high speed machines and low loss bearing systems. 
Peter E. Kascak received his B.S.E.C.E. and M.S.E.E. from The Ohio State University in 1997 and 1999 respectively. From 1996 to 1998 he worked as a summer intern at the NASA Glenn Research Center (GRC) in Cleveland, Ohio. From 1997 to 1999 he was a member of the analog Very Large Scale Integration (VLSI) laboratory at The Ohio State University. In 2000, Mr. Kascak was part of a team that spun a flywheel energy storage system to $60 \mathrm{kRPM}$. He also developed electronics and software for the magnetic bearing control system used to levitate the flywheels at GRC. In addition, he works on motor control for the flywheel energy storage system at GRC including the development, simulation and implementation of a simultaneous bus and attitude controller.

Mr. Kascak is employed by the University of Toledo as a Senior Research Associate supporting GRC and is currently pursuing a Ph.D. at Case Western Reserve University. His research is in the area of controls and motor design.

Timothy Dever is an Electrical Engineer working for QSS Group, Inc., supporting the Space Power and Propulsion Test Engineering Branch at the NASA Glenn Research
Center, where he has worked since 1999 . He is currently working on magnetic bearing controllers for use in flywheel energy storage systems for space applications.

Mr. Dever received his B.S.E.E. from Cleveland State University in 1987 and his M.S.E.E. from Case Western Reserve University in 1991. He worked at General Electric's Lighting Division from 1987-1999

Walter Santiago is an Electrical Engineer in the Electrical Systems Development Branch at the NASA Glenn Research Center, Cleveland, Ohio, where he has worked since 1989. $\mathrm{He}$ is currently working on developing power electronic components and circuits to support the flywheel technology program. He has previously worked developing controls for stirling engines and in test and verification of DC-DC converters and switchgear for the International Space Station.

Mr. Santiago received his B.S.E.E. from the University of Puerto Rico, Mayagüez campus in 1989 and an M.S.E.E. from Cleveland State University in 1994. 


\begin{tabular}{|c|c|c|}
\hline \multicolumn{2}{|c|}{ REPORT DOCUMENTATION PAGE } & $\begin{array}{l}\text { Form Approved } \\
\text { OMB No. 0704-0188 }\end{array}$ \\
\hline \multicolumn{3}{|c|}{$\begin{array}{l}\text { Public reporting burden for this collection of information is estimated to average } 1 \text { hour per response, including the time for reviewing instructions, searching existing data sources, } \\
\text { gathering and maintaining the data needed, and completing and reviewing the collection of information. Send comments regarding this burden estimate or any other aspect of this } \\
\text { collection of information, including suggestions for reducing this burden, to Washington Headquarters Services, Directorate for Information Operations and Reports, } 1215 \text { Jefferson } \\
\text { Davis Highway, Suite 1204, Arlington, VA 22202-4302, and to the Office of Management and Budget, Paperwork Reduction Project (0704-0188), Washington, DC } 20503 .\end{array}$} \\
\hline 1. AGENCY USE ONLY (Leave blank) & \begin{tabular}{|c|c|} 
2. REPORT DATE & 3. \\
February 2004 &
\end{tabular} & $\begin{array}{l}\text { D DATES COVERED } \\
\text { echnical Memorandum }\end{array}$ \\
\hline \multicolumn{2}{|c|}{$\begin{array}{l}\text { 4. TITLE AND SUBTITLE } \\
\text { Demonstration of Single Axis Combined Attitude Control and Energy Storage } \\
\text { Using Two Flywheels }\end{array}$} & \multirow{2}{*}{$\begin{array}{l}\text { 5. FUNDING NUMBERS } \\
\text { WBS-22-755-60-12 }\end{array}$} \\
\hline \multicolumn{2}{|c|}{$\begin{array}{l}\text { 6. AUTHOR(S) } \\
\text { Barbara H. Kenny, Ralph Jansen, Peter Kascak, Timothy Dever, } \\
\text { and Walter Santiago }\end{array}$} & \\
\hline $\begin{array}{l}\text { 9. SPONSORING/MONITORING AGE } \\
\text { National Aeronautics and } \mathrm{S}_{\mathrm{I}} \\
\text { Washington, DC 20546-00 }\end{array}$ & $\begin{array}{l}\text { NAME(S) AND ADDRESS(ES) } \\
\text { Administration }\end{array}$ & $\begin{array}{l}\text { 10. SPONSORING/MONITORING } \\
\text { AGENCY REPORT NUMBER } \\
\text { NASA TM-2004-212935 } \\
\text { IEEEAC } 1261\end{array}$ \\
\hline
\end{tabular}

Prepared for the 2004 Aerospace Conference sponsored by the Institute of Electrical and Electronics Engineers, Big Sky, Montana, March 6-13, 2004. Barbara H. Kenny and Walter Santiago, NASA Glenn Research Center; Ralph Jansen and Peter Kascak, University of Toledo, Toledo, Ohio 43606; and Timothy Dever, QSS Group, Inc., Cleveland, Ohio 44135. Responsible person, Barbara Kenny, organization code 5450, 216-433-6289.

12a. DISTRIBUTION/AVAILABILITY STATEMENT 12b. DISTRIBUTION CODE

Unclassified - Unlimited

Subject Categories: 44 and 20

Distribution: Nonstandard

Available electronically at http://gltrs.grc.nasa.gov

This publication is available from the NASA Center for AeroSpace Information, 301-621-0390.

13. ABSTRACT (Maximum 200 words)

The energy storage and attitude control subsystems of the typical satellite are presently distinct and separate. Energy storage is conventionally provided by batteries, either $\mathrm{NiCd}$ or $\mathrm{NiH}$, and active attitude control is accomplished with control moment gyros (CMGs) or reaction wheels. An overall system mass savings can be realized if these two subsystems are combined using multiple flywheels for simultaneous kinetic energy storage and momentum transfer. Several authors have studied the control of the flywheels to accomplish this and have published simulation results showing the feasibility and performance. This paper presents the first experimental results showing combined energy storage and momentum control about a single axis using two flywheels.

14. SUBJECT TERMS

Flywheel energy storage; Attitude control; Permanent magnet motor control

\begin{tabular}{|c|c|c|c|}
\hline $\begin{array}{c}\text { 17. SECURITY CLASSIFICATION } \\
\text { OF REPORT } \\
\text { Unclassified }\end{array}$ & $\begin{array}{c}\text { 18. SECURITY CLASSIFICATION } \\
\text { OF THIS PAGE } \\
\text { Unclassified }\end{array}$ & $\begin{array}{c}\text { 19. SECURITY CLASSIFICATION } \\
\text { OF ABSTRACT } \\
\text { Unclassified }\end{array}$ \\
\hline
\end{tabular}

NSN 7540-01-280-5500

Standard Form 298 (Rev. 2-89)

Prescribed by ANSI Std. Z39-18 298-102 